\title{
Role of co-regulators in metabolic and transcriptional actions of thyroid hormone
}

\section{Inna Astapova}

Division of Endocrinology, Diabetes and Metabolism, Beth Israel Deaconess Medical Center and Harvard Medical School, Boston, Massachusetts, USA
Correspondence should be addressed to I Astapova Email

iastapov@bidmc.harvard.edu

\begin{abstract}
Thyroid hormone (TH) controls a wide range of physiological processes through $\mathrm{TH}$ receptor (TR) isoforms. Classically, TRs are proposed to function as tri-iodothyronine $\left(\mathrm{T}_{3}\right)$-dependent transcription factors: on positively regulated target genes, unliganded TRs mediate transcriptional repression through recruitment of co-repressor complexes, while $\mathrm{T}_{3}$ binding leads to dismissal of co-repressors and recruitment of co-activators to activate transcription. Co-repressors and co-activators were proposed to play opposite roles in the regulation of negative $T_{3}$ target genes and hypothalamic-pituitary-thyroid axis, but exact mechanisms of the negative regulation by $\mathrm{TH}$ have remained elusive. Important insights into the roles of co-repressors and co-activators in different physiological processes have been obtained using animal models with disrupted co-regulator function. At the same time, recent studies interrogating genome-wide TR binding have generated compelling new data regarding effects of $T_{3}$, local chromatin structure, and specific response element configuration on TR recruitment and function leading to the proposal of new models of transcriptional regulation by TRs. This review discusses data obtained in various mouse models with manipulated function of nuclear receptor co-repressor (NCOR or NCOR1) and silencing mediator of retinoic acid receptor and thyroid hormone receptor (SMRT or NCOR2), and family of steroid receptor co-activators (SRCs also known as NCOAs) in the context of TH action, as well as insights into the function of co-regulators that may emerge from the genome-wide TR recruitment analysis.
\end{abstract}

Journal of Molecular Endocrinology (2016) 56, R73-R97

\section{Introduction}

Thyroid hormone (TH) is essential for normal development, growth, reproduction, and regulation of metabolism and thermogenesis in mammals. Circulating TH levels are tightly controlled by a negative feedback within hypothalamic-pituitary-thyroid (HPT) axis, where thyrotrophin-releasing hormone (TRH) from the hypothalamus stimulates production and secretion of thyroid-stimulating hormone (TSH) by the pituitary, which in turn stimulates synthesis, processing, and
Key Words
- thyroid hormone receptors
- nuclear co-repressor
- steroid receptor co-activator
- animal models
- transcription 
5'-deiodinases (DIO1 and DIO2) convert $\mathrm{T}_{4}$ into active $\mathrm{T}_{3}$, and type $35^{\prime}$-deiodinase (DIO3) inactivates $\mathrm{T}_{4}$ and $\mathrm{T}_{3}$ to form reverse $\mathrm{T}_{3}$ and $\mathrm{T}_{2}$, respectively (Arrojo et al. 2013, Charalambous \& Hernandez 2013, Gereben et al. 2008). Actions of deiodinases and transporters are crucial for normal maintenance of both intracellular and circulating TH levels, as well as function of HPT axis (Bernal et al. 2015, Fonseca et al. 2013, Hernandez et al. 2007, Heuer \& Visser 2013, Hoftijzer et al. 2011, Schweizer \& Kohrle 2013). Physiological effects of TH are largely mediated by regulation of gene transcription by $\mathrm{TH}$ receptors (TRs): ligand-dependent transcription factors that belong to the nuclear receptor (NR) superfamily. Two different genes (Thra and Thrb) encode the THRA and THRB subtypes and produce three main $\mathrm{T}_{3}$-binding isoforms THRA1, THRB1, and THRB2, which are expressed in a tissue-specific and developmentally regulated manner (Cheng et al. 2010, Hodin et al. 1989, Koenig et al. 1988, Sap et al. 1986, Weinberger et al. 1986, Zhang \& Lazar 2000). TRs regulate transcription of target genes by binding thyroid hormone response elements (TRE) in their regulatory regions as homodimers or heterodimers with retinoid $\mathrm{X}$ receptors (RXR). Soon after the cloning of first TR isoforms, it had become apparent that in addition to $\mathrm{T}_{3}$-dependent activation of transcription, TRs possess the capability to silence target genes in the absence of TH (Brent et al. 1989, Damm etal. 1989). Experiments designed to isolate proteins that interact with either ligand-bound or unliganded NRs confirmed the important role of these receptor-associated proteins in transcriptional regulation by NRs and led to identification and cloning of the first co-activators, such as steroid receptor co-activators 1-3 (SRC1-3, also known as NCOA1-3) and co-repressors: nuclear receptor co-repressor (NCoR or NCOR1) and silencing mediator of retinoic acid receptor and thyroid hormone receptor (SMRT or NCOR2) (Baniahmad et al. 1995, Cavailles et al. 1994, Chen et al. 1997, Chen \& Evans 1995, Halachmi et al. 1994, Horlein et al. 1995, Onate et al. 1995, Torchia et al. 1997, Voegel et al. 1996). Since then, over 300 nuclear receptor co-regulators have been identified (https://www. nursa.org/nursa/molecules/index.jsf) representing very diverse group of proteins, which are broadly defined by their role in regulation of transcription and inability to directly bind DNA. Co-regulators may serve as a bridge between NRs and basic transcriptional machinery, but most importantly play a key role in recruitment and function of complexes that mediate ATP-dependent chromatinremodeling or histone modifications, such as acetylation, methylation, ubiquitylation, and others, which change chromatin structure and accessibility and ultimately lead to activation or repression of transcription (Kouzarides 2007, Millard et al. 2013, Strahl \& Allis 2000, Suganuma \& Workman 2008). Interactions between co-regulators and NRs are mediated by specific receptor-interacting domains (RIDs) that are characterized by a presence of LXXLL motif, termed NR box, in co-activators (Heery et al. 1997) and a LXXH/IIXXXI/L CoRNR box in co-repressor proteins (Hu \& Lazar 1999, Nagy et al. 1999, Perissi et al. 1999). The specificity of interactions between co-regulators and NRs is thought to be encoded by the differences in the co-regulator RIDs and surrounding amino acid sequence. Co-repressors and co-activators are recruited to the same surface on the ligand-binding domain (LBD) of NRs, in a mutually exclusive manner (Darimont et al. 1998, Feng et al. 1998, Nolte et al. 1998, Wang et al. 2006, $\mathrm{Xu}$ et al. 2002): generally co-repressors are recruited to unliganded or antagonist-bound NR, while ligands induce a conformational change in helix 12 of LBD that favors recruitment of co-activators (Millard et al. 2013, Nagy et al. 1999, Perissi et al. 1999, Watson et al. 2012).

Based on this, the bimodal switch model of TR action has been proposed, where TRs are postulated to bind the DNA independent of the hormone. On a positively regulated target gene, co-repressors are recruited to unliganded TRs and bring enzymatic complexes, importantly histone deacetylases (HDACs), which modify histones and chromatin structure to actively repress transcription. Hormone binding induces a conformational change in the receptor that leads to the dismissal of co-respressors and their replacement by co-activators that bring enzymatic complexes with opposing activities, such as histone acetylases (HATs), to activate transcription (Glass \& Rosenfeld 2000, McKenna $\&$ O'Malley 2002). The importance of transcriptional repression by unliganded TRs is underscored by the fact that neonatal hypothyroidism presents with much more sever phenotype than mouse models deficient in all TRs and the fact that athyroid mice can be rescued by TR deletion (Flamant et al. 2002, Flamant \& Samarut 2003). At the same time, the mechanism of transcriptional regulation of negative TR targets, such as Tshb gene, which are activated by unliganded TR and repressed upon the $\mathrm{T}_{3}$ binding, is less clear (Darling et al. 1989). It has been suggested that the co-repressors and co-activators may play opposite functions on this type of target genes, but precise molecular mechanism underlying these effects is still lacking. Inappropriate recruitment of $\mathrm{CoA}$ and $\mathrm{CoR}$ is also thought to play a role in the phenotypic presentation of the syndrome of resistance to thyroid hormone (RTH) as discussed below.

Published by Bioscientifica Ltd. 
In this review, we will focus on the data regarding the in vivo role of co-regulators in TR action obtained from animal models and also incorporate some insights from recent genome-wide TR chromatin occupancy studies. Since the discovery of the SRC family and NCoR/SMRT, many cofactors have been shown to bind and modulate TR activity (at least in vitro), including co-activators thyroid hormone receptorassociated protein 220 (TRAP220 or MED1) (Ito \& Roeder 2001), peroxisome proliferator-activated receptor gamma (PPARG) co-activator-1a (PGC-1a or PPARGC1A) (Wu et al. 2002), and co-repressors receptor interacting protein 140 (RIP140 or NRIP1) (Moore et al. 2004), and liganddependent co-repressor (LCOR) (Song et al. 2012), reviewed by Moore and Guy (2005) and Yao (2014). However, we will limit the review to SRC/p160 family of co-activators and co-repressors NCoR and SMRT, as they are the best studied in vivo in the context of TR signaling.

\section{Structural and functional domains of co-regulator proteins}

The SRC/p160 family of co-activators consists of three closely related proteins: SRC1, -2, and -3 (NCOA1, 2 and 3, respectively), with a molecular weight around $160 \mathrm{kDa}$, and overall sequence similarity of $50-55 \%$, which contain three main functional domains (Dasgupta et al. 2014, Johnson \& O'Malley 2012, Xu \& Li 2003) (Fig. 1A). The N-terminal basic helix-loop-helix-Per/ARNT/Sim (b-HLH-PAS) domain is the most conserved among the family members. It is not necessary for co-activation of NRs, but interacts with several other transcription factors, contains a nuclear localization signal, and renders SRCs sensitive to proteasome-dependent turnover (Li et al. 2007, Onate et al. 1995). The central part of the SRC molecule contains three copies of the LXXLL motif (NR box), which are responsible for direct interactions with NRs (Chen et al. 1997, Heery et al. 1997, Voegel et al. 1998). Mutational analysis and in vitro interaction studies have demonstrated that distinct amino acid sequences of LXXLL motifs and adjacent portion of the protein dictate specificity of NR-LXXLL motif interactions, so that different co-activators or NR boxes within the same co-activator show preferential binding to certain NRs (McInerney et al. 1998, Moore et al. 2004). It has also been suggested that SRCs can bind the N-terminal portion of THRB isoforms through noncanonical NR-binding domains in a $\mathrm{T}_{3}$-independent manner, which may potentially play an important role in the upregulation of TRH and TSH genes in the absence of hormone (Iwasaki et al. 2006, Yang \& Privalsky 2001). Finally, two activation domains
$\mathrm{AD} 1$ and $\mathrm{AD} 2$, located in the C-terminus, are responsible for recruitment of additional chromatin-modifying co-regulator complexes such as CREB-binding protein (CBP)/p300 possessing HAT, co-activator-associated arginine methyltransferase 1 (CARM1), and protein arginine $N$-methyl transferase 1 (PRMT1) (Chen et al. 1999, Dasgupta et al. 2014, Koh et al. 2001, Li et al. 2000, Onate et al. 1998, Voegel et al. 1998, Xu \& Li 2003). AD1 domain also contains three LXXLL-like motifs; however, interaction studies have shown that they are not involved

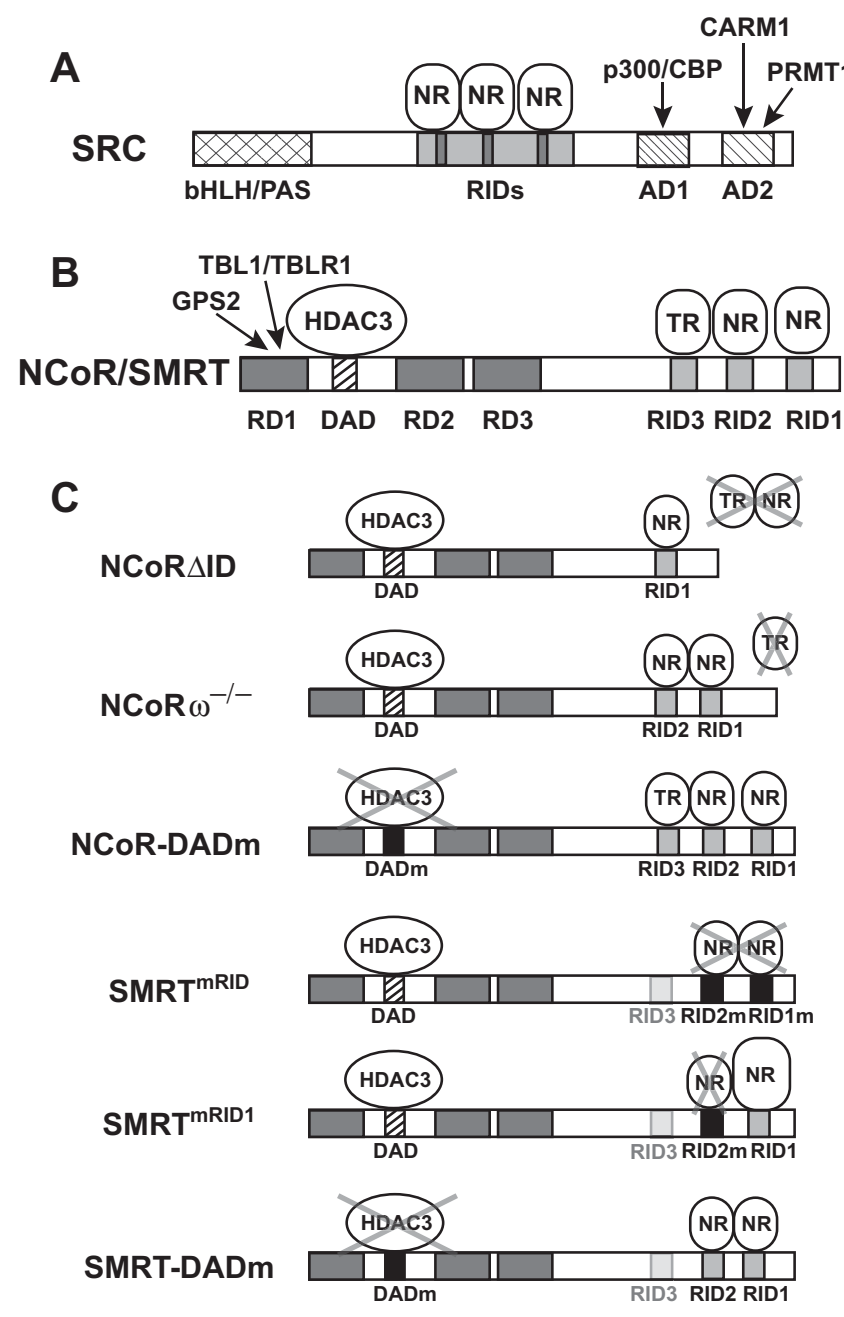

Figure 1

Schematic representation of the structure of wt SRC family members (A), wt NCoR and SMRT (B), and various genetically modified co-repressor mutants discussed in this review (C). Locations of bHLH/PAS domain, activating domains (AD), receptor-interacting domains (RID), repression domains (RD), and deacetylase activation domain (DAD) are indicated by boxes within the co-regulator molecules. Interactions between co-regulators and NRs, and co-repressors and HDAC3 are shown. Regions of other cofactor recruitment are indicated by arrows. RID3 of SMRT is shown in lighter color to reflect the fact that the predominantly expressed SMRT isoform contains only RID2 and RID1.

Published by Bioscientifica Ltd. 
in recruitment of SRCs to DNA-bound TR (Takeshita et al. 1998). In addition, SRCs have weak intrinsic HAT activity located in their C-terminal domain (Feng et al. 2009).

NCoR and SMRT are highly homologous (40\% amino acid identity) large proteins of $270 \mathrm{kDa}$, containing conserved functional domains (Fig. 1B). For comprehensive review of co-repressor structure and complexes, see Millard et al. (2013), Perissi et al. (2010), and Watson et al. (2012). Three repression domains (RD1-3) are located within the N-terminal portion of NCoR and SMRT and mediate transcriptional repression through recruitment of a multiprotein repression complex (Alland et al. 1997, Heinzel et al. 1997, Nagy et al. 1997). Located in the N-terminus is also deacetylase activation domain (DAD), the region of the co-repressors responsible for recruitment and activation of histone deacetylase 3 (HDAC3), which deacetylates histone tails leading to chromatin remodeling and transcriptional repression (Guenther et al. 2001, Guenther et al. 2000, Ishizuka \& Lazar 2003, 2005, You et al. 2013). HDAC3 appears to be the main enzyme responsible for the repressive activity of SMRT and NCoR, because it is the protein that associates in the most stable and reproducible way with both co-repressors. Although co-repressor complexes are heterogeneous and context-specific, some proteins are regularly found in stoichiometric association with NCoR/SMRT and appear to be essential for their repressive function. In addition to HDAC3, these partners include $G$ protein pathway suppressor (GPS2) and transducin $\beta$-like 1 (TBL1 or TBL1X) and its homolog, TBL-related 1 (TBLR1 or TBL1XR1), which all together form the core repression complex (Oberoi et al. 2011). Both TBL1 and TBLR1 are responsible for ubiquitylation-dependent dismissal of the CoR complex, while GPS2 appears to be structurally required for maintenance of this complex (Oberoi et al. 2011, Yoon et al. 2003). The C-terminus of co-repressor proteins contains three RIDs that are characterized by a presence of CoRNR box, which is essential for NR-binding as outlined above (Hu \& Lazar 1999, Nagy et al. 1999, Perissi et al. 1999). The exons encoding RIDs are subject to alternative splicing that produces different co-repressor isoforms, which are expressed in a tissue-specific manner (Faist et al. 2009, Goodson et al. 2011, Malartre et al. 2004). Interestingly, amino acid sequences of specific RIDs dictate the preferential binding to different NRs, with most N-terminal of the RIDs (N3 in NCoR and S3 in SMRT) having the highest avidity for TR, while S2 has demonstrated preference for the retinoic acid receptor (RAR) (Cohen et al. 2001,
Cohen et al. 2000, Makowski et al. 2003, Webb et al. 2000). Because of these differences in binding of specific RIDs to the TRs, it has been hypothesized that NCoR and SMRT play nonredundant roles in the TR actions in vivo.

\section{Animal models of co-regulator function}

Mice deficient for individual members of the p160 family have first proved the importance of SRC proteins for full physiological response to sex steroids and growth hormone in vivo. Decreased growth of organs highly responsive to steroids (testis, uterus, and mammary gland) was observed $\mathrm{SrC1}^{-/-}$and $\mathrm{Src} 2^{-/-}$, and accompanied by reduced reproductive function in $\mathrm{Src}^{-/-}$mice (Gehin et al. 2002, Xu et al. 1998). Defective growth hormone signaling and estrogen production resulting in short stature and reduced female reproductive function were reported in Src3-/- mice (Wang et al. 2000, Xu et al. 2000). These findings established that $\mathrm{p} 160$ co-regulators possess certain functional specificity in vivo (recently reviewed in Dasgupta et al. 2014, Dasgupta \& O'Malley 2014, Stashi et al. 2014b). Data obtained from these animal models pertinent to $\mathrm{TH}$ signaling and metabolic regulation is discussed below in the sections 'Roles of co-regulators in peripheral tissues' and 'Roles of co-regulators in the funtion of HPT axis and RTH'.

At the same time, the first attempts to elucidate in vivo roles of co-repressors revealed that NCoR and SMRT play nonredundant roles in mammalian development and have physiologic functions beyond NR signaling, as germline knockout of either co-repressor resulted in embryonic lethality (Jepsen et al. 2000, Jepsen et al. 2007). $\mathrm{NCoR}^{-/-}$animals have defects in thymocyte and neuronal differentiation and definitive erythropoiesis, which result in embryonic death by E15.5 (Jepsen et al. 2000). Knockout of Smrt revealed its critical role in heart development through its interactions with a forkhead protein FOXP1. Furthermore, interactions of SMRT with RAR and Notch signaling pathway are responsible for normal forebrain development and maintenance of the neural stem cell state (Jepsen et al. 2008). A different whole-body SMRT-deficient mouse model was also found to be embryonic lethal, and analysis of $\mathrm{Smrt}^{+/-}$ animals revealed that SMRT plays an important role in adipogenesis (Sutanto et al. 2010). To better understand physiological function of NCoR and SMRT in adult animal and their role in specific NR signaling, several conditional knockout and mutant knock-in models were generated.

Published by Bioscientifica Ltd. 
A conditional NCoR null allele that can produce complete deletion of NCoR in a tissue-specific manner was described and used to generate muscle-, adipocyte-, and liver-specific NCoR knockout mice (Jo et al. 2015, Li et al. 2011, Sun et al. 2013, Yamamoto et al. 2011). A conditional Smrt knockout allele has also been generated, and liver-specific and adult whole-body Smrt knockout models have been published (Shimizu et al. 2015, Sun et al. 2013).

Presence of distinct functional domains in the CoR proteins makes them ideal targets for genetic manipulations that affect one specific function (Fig. 1C). As outlined above, both NCoR and SMRT have three C-terminal RIDs, that preferentially bind different NRs (Cohen et al. 2001, Cohen et al. 2000, Faist et al. 2009, Goodson et al. 2011, Makowski et al. 2003, Malartre et al. 2004, Webb et al. 2000). This feature makes targeting of specific RID an attractive strategy to address the role of co-repressors in the action of specific NRs as well as physiological significance of different co-repressor isoforms. To this end, mice bearing a conditional allele encoding for a mutant $\mathrm{NCoR}$, termed NCoR $\Delta$ ID, that is lacking the two N-terminal RID domains and is unable to interact with TR and liver $\mathrm{X}$ receptor (LXR) isoforms were generated (Astapova et al. 2008). Recently, Goodson et al. (2014) reported a mouse model $\left(\mathrm{NCoR}^{-/-}\right)$with a mutation introduced into a splicing site, which results in the inability to produce the full-length $N C o R \omega$ isoform, and global expression of $N C o R \delta$, containing only RID2 and RID1. In a similar approach, the SmrtmRID knock-in mouse model was created, where mutations were introduced into RID1 and RID2 domains, so that the resulting mutant Smrt ${ }^{m R I D}$ loses its ability to interact with RAR, TR, and PPAR isoforms (Nofsinger et al. 2008). In Smrt ${ }^{m R I D 1}$ mice, the mutation that abolishes binding to NRs was only introduced into one of the two RIDs, shown as RID2 in Fig. 1B. This leads to an enhanced recruitment of SMRT to NRs that preferably utilize the remaining C-terminal RID (Fig. 1C), particularly PPARs (Fang et al. 2010, Reilly et al. 2010).

As the CoRs are thought to exert much of their repressive actions by recruiting and activating HDAC3 (Guenther et al. 2001), mice bearing inactivating mutation in DAD of NCoR (N-DADm) and SMRT (S-DADm) were also generated and characterized (Alenghat et al. 2008, You et al. 2013). As was shown later, while this mutation eliminates HDAC3 activity, it does not completely abolish recruitment of HDAC3 by co-repressors, which preserves nonenzymatic repressive functions of HDAC3 (Sun et al. 2013).

\section{Roles of co-regulators in peripheral tissues}

While efforts have been made to address the specificity of co-regulator-NR interactions, in many in vivo models where co-regulator function has been manipulated, it may be difficult to attribute the physiologic effects to a specific transcription factor. TR isoforms and co-regulators are widely expressed and control multiple metabolic pathways (Brent 2012, Cheng et al. 2010, Dasgupta et al. 2014, Mottis et al. 2013, Obregon 2014). In many tissues, including liver, muscle, white and brown adipose tissues, and brain, there is a significant interplay between different NRs. For example in the liver, enzymes involved in fatty acid, carbohydrate, cholesterol, and bile acid metabolism are controlled by various NRs, including TRs, LXRs, PPARs, liver receptor homolog-1 (LRH-1 or NR5A2), Rev-ErbA (NR1D1), and others. The mechanisms of interplay may include: binding of different NRs to specific response elements located in the promoter/enhancer regions of the same gene; regulation of TH metabolism by other NRs; competition for dimerization partners and co-regulators (squelching); and competition for binding to the same NR response element, particular for LXRs, which share the same preferred response element: direct repeat with a 4 nucleotide spacer (DR-4) (Brent 2012, Cheng et al. 2010, Christoffolete et al. 2010, Hashimoto \& Mori 2011, Maglich et al. 2004, Miao et al. 2015, Qatanani et al. 2005). Furthermore, recent genome-wide recruitment studies demonstrated that even NRs with different preferred DNA-binding elements share a great percentage of the binding sites under nonstimulated conditions in the liver (Boergesen et al. 2012). Therefore, we will briefly summarize the results of the in vivo co-regulator studies with a focus on TH signaling through the TR (Table 1).

\section{Src1 knockout mice}

Mouse knockout models identified SRC co-activators as essential regulators of energy homeostasis as they modulate expression of multiple enzymes in different metabolic pathways and tissues (Dasgupta et al. 2014, Dasgupta \& O'Malley 2014, Stashi et al. 2014b).

Src1 knockout mice demonstrate increased weight gain when fed high-fat diet, presumably due to reduced energy expenditure (EE) and defective adaptive thermogenesis likely resulting from the loss of PPARGC1A co-activation by Src1 (Picard et al. 2002). At the same time, lack of SRC1 also leads to hypoglycemia in fed and fasting states, at least partly due to impaired hepatic gluconeogenesis, as SRC1 is involved in activation of transcription of key

Published by Bioscientifica Ltd 
Table 1 Summary of phenotypes of mouse models discussed in the review as related to TH signaling in peripheral tissues.

\begin{tabular}{|c|c|c|c|c|}
\hline Mouse model & Phenotype & $\begin{array}{l}\text { TF responsible for the } \\
\text { phenotype as discussed } \\
\text { in original paper }\end{array}$ & References & $\begin{array}{l}\text { Possible TR involvement, if } \\
\text { not the primary focus of } \\
\text { original paper }\end{array}$ \\
\hline \multirow[t]{4}{*}{$\operatorname{Src1} 1^{-1-}(\operatorname{Ncoa} 1)$} & $\begin{array}{l}\text { Obesity on high-fat diet due to } \\
\text { reduced } \mathrm{EE} \text { and defective } \\
\text { adaptive thermogenesis }\end{array}$ & PPARRGC1A & Picard et al. (2002) & $\begin{array}{l}\text { Possible: TRs control EE and } \\
\text { expression and activation of } \\
\text { uncoupling protein } 1 \text { (UCP1). }\end{array}$ \\
\hline & Impaired hepatic gluconeogenesis & CEBPA & Louet et al. (2010) & $\begin{array}{l}\text { Possible: TH regulates } \\
\text { expression of glucose- } \\
\text { 6-phosphatase }\end{array}$ \\
\hline & Perturbed amino acid metabolism & & $\begin{array}{l}\text { Tannour-Louet } \\
\text { et al. (2014) }\end{array}$ & Unclear \\
\hline & $\begin{array}{l}\text { Hyposensitivity to TH in the liver; } \\
\text { dysregulated control of heart } \\
\text { rate }\end{array}$ & TRs & $\begin{array}{l}\text { Sadow et al. } \\
\text { (2003a); Vella } \\
\text { et al. (2014) }\end{array}$ & \\
\hline \multirow[t]{6}{*}{$\operatorname{Src2} 2^{-1-}($ Ncoa 2$)$} & $\begin{array}{l}\text { Lean, increased glucose toler- } \\
\text { ance, and insulin resistance on } \\
\text { high-fat diet. Increased basal } \\
\text { and stimulated lipolysis, } \\
\text { elevated EE }\end{array}$ & PPARG & Picard et al. (2002) & $\begin{array}{l}\text { Unlikely: the phenotype is } \\
\text { opposite of what would } \\
\text { be expected in case of lack } \\
\text { of TR co-activation }\end{array}$ \\
\hline & Impaired hepatic glucose release & RORA & $\begin{array}{l}\text { Chopra et al. } \\
\text { (2008) }\end{array}$ & $\begin{array}{l}\text { Possible: TH regulates } \\
\text { expression of glucose- }\end{array}$ \\
\hline & Diminished fat absorption due to & FXR & & 6-phosphatase \\
\hline & $\begin{array}{l}\text { downregulation of bile salt } \\
\text { export pump }\end{array}$ & & $\begin{array}{l}\text { Chopra et al. } \\
\text { (2011) }\end{array}$ & \\
\hline & Impaired circadian regulation of & ARNTL, CLOCK & & export pump \\
\hline & $\begin{array}{l}\text { lipid and glucose metabolism } \\
\text { genes }\end{array}$ & & $\begin{array}{l}\text { Stashi et al. } \\
\quad(2014 a)\end{array}$ & $\begin{array}{l}\text { Possible: TRs regulate expres- } \\
\text { sion of lipogenic and } \\
\text { gluconeogenic genes }\end{array}$ \\
\hline \multirow[t]{3}{*}{$\mathrm{Src3}^{-1-}(\mathrm{Ncoa} 3)$} & $\begin{array}{l}\text { Decreased adipocyte differentia- } \\
\text { tion and expression of PPAR- } \gamma 2\end{array}$ & CEBPA & Louet et al. (2006) & Unclear \\
\hline & $\begin{array}{l}\text { Improved glucose and lipid } \\
\text { metabolism, resistance to } \\
\text { diet-induced obesity, and } \\
\text { increased EE }\end{array}$ & PPARGC1A & Coste et al. (2008) & $\begin{array}{l}\text { Unlikely: the phenotype is } \\
\text { opposite of what would } \\
\text { be expected in case of lack } \\
\text { of TR co-activation }\end{array}$ \\
\hline & $\begin{array}{l}\text { Impaired metabolism of long } \\
\text { chain fatty acids }\end{array}$ & & & \\
\hline$N C o R^{-I-}($ Ncor 1$)$ & $\begin{array}{l}\text { Embryonic lethality, impaired } \\
\text { erythropoiesis, thymocyte, and } \\
\text { neuronal differentiation }\end{array}$ & RAR, possibly TRs & $\begin{array}{l}\text { Jepsen et al. } \\
\quad(2000)\end{array}$ & \\
\hline Smrtt-l-(Ncor2) & $\begin{array}{l}\text { Embryonic lethality, defects in } \\
\text { heart development, } \\
\text { unrestricted neural stem cell } \\
\text { differentiation, and impaired } \\
\text { forebrain development }\end{array}$ & FOXP1, RAR, Notch & $\begin{array}{l}\text { Jepsen et al. } \\
\quad(2007,2008)\end{array}$ & Unclear \\
\hline Smrtt- & $\begin{array}{l}\text { Obesity with higher number of } \\
\text { smaller adipocytes on high-fat } \\
\text { diet }\end{array}$ & Possibly PPARG & $\begin{array}{l}\text { Sutnato et al. } \\
\quad(2010)\end{array}$ & $\begin{array}{l}\text { Possibly: TRs regulate } \\
\text { adipogenesis, lipogenesis, } \\
\text { and lipolysis }\end{array}$ \\
\hline $\begin{array}{r}\text { Liver-specific } \\
\text { L-NCoR } \triangle I D\end{array}$ & $\begin{array}{l}\text { Increased expression of hepatic } \\
\text { TR targets in both hypo- and } \\
\text { euthyroid conditions }\end{array}$ & TRs, LXRs & $\begin{array}{l}\text { Astapova et al. } \\
\text { (2008) }\end{array}$ & \\
\hline & Upregulation of LXR target genes & & & \\
\hline \multirow[t]{2}{*}{$N C O R \Delta I D$} & $\begin{array}{l}\text { Increased sensitivity to TH in } \\
\text { some peripheral tissues, } \\
\text { increased EE }\end{array}$ & TRs & $\begin{array}{l}\text { Astapova et al. } \\
\text { (2011) }\end{array}$ & \\
\hline & $\begin{array}{l}\text { Ameliorates to some degree } \\
\text { peripheral presentations of } \\
\mathrm{TRB}^{\mathrm{PV} /+} \text { and } \mathrm{TRA} 1^{\mathrm{PV} /+} \mathrm{RTH}\end{array}$ & & $\begin{array}{l}\text { Fozatti et al. } \\
\text { (2011); Fozatti } \\
\text { et al. (2013) }\end{array}$ & \\
\hline $\begin{array}{l}\text { NCoRAID } \\
\text { Src1-/- }\end{array}$ & $\begin{array}{l}\text { Normalized sensitivity to } \mathrm{TH} \text { in } \\
\text { the liver }\end{array}$ & TRs & Vella et al. (2014) & \\
\hline
\end{tabular}


Table 1 (Continued)

\begin{tabular}{|c|c|c|c|c|}
\hline Mouse model & Phenotype & $\begin{array}{l}\text { TF responsible for the } \\
\text { phenotype as discussed } \\
\text { in original paper }\end{array}$ & References & $\begin{array}{l}\text { Possible TR involvement, if } \\
\text { not the primary focus of } \\
\text { original paper }\end{array}$ \\
\hline \multirow[t]{3}{*}{ NCoR-DADm } & $\begin{array}{l}\text { Abnormal circadian behavior } \\
\text { and expression of lipid } \\
\text { metabolism genes, reduced } \\
\text { fat mass, increased insulin } \\
\text { sensitivity }\end{array}$ & $\begin{array}{l}\text { Lack of HDAC3 } \\
\text { recruitment to: } \\
\text { Rev-ErbA }\end{array}$ & $\begin{array}{l}\text { Alenghat et al. } \\
\text { (2008) }\end{array}$ & $\begin{array}{l}\text { Possible: TRs regulate } \\
\text { expression of lipogenic } \\
\text { genes }\end{array}$ \\
\hline & $\begin{array}{l}\text { Derepression of TR targets } \\
\text { in hypo- and euthyroid } \\
\text { states }\end{array}$ & TRs & You et al. (2010) & \\
\hline & $\begin{array}{l}\text { Impaired TH-induced } \\
\text { autophagy and fatty } \\
\text { acid B-oxidation in the } \\
\text { liver }\end{array}$ & TRs & Sinha et al. (2012) & \\
\hline NCoR/Smrt-DADm & $\begin{array}{l}\text { Upregulation of lipogenic } \\
\text { genes in the liver, mild } \\
\text { hepatic steatosis }\end{array}$ & $\begin{array}{l}\text { General lack of } \\
\text { HDAC3 activation }\end{array}$ & You et al. (2013) & Very likely, among other NRs \\
\hline $\begin{array}{l}\text { Liver-specific } \\
\text { Hdac3--- }^{-1}\end{array}$ & $\begin{array}{l}\text { Hepatomegaly and severe } \\
\text { liver steatosis Dysregulation } \\
\text { of carbohydrate and lipid } \\
\text { metabolism genes }\end{array}$ & $\begin{array}{l}\text { General lack of } \\
\text { HDAC3 }\end{array}$ & $\begin{array}{l}\text { Knutson et al. } \\
\text { (2008), Feng } \\
\text { et al. (2011) }\end{array}$ & Very likely, among other NRs \\
\hline $\begin{array}{l}\text { Liver-specific } \\
\quad N C o R^{-/-}\end{array}$ & $\begin{array}{l}\text { Upregulation of genes in NADPH } \\
\text { and lipid synthesis, lipid } \\
\text { sequestration, fatty acid } \\
\text { oxidation. Significant } \\
\text { hepatosteatosis }\end{array}$ & $\begin{array}{l}\text { LXRA, PPARA, ESRRA, } \\
\text { Rev-ErbA }\end{array}$ & $\begin{array}{l}\text { Sun et al. (2013), } \\
\text { Jo et al. (2015) }\end{array}$ & $\begin{array}{l}\text { Very likely: TRs regulate lipid } \\
\text { synthesis and fatty acid } \\
\text { oxidation }\end{array}$ \\
\hline $\begin{array}{l}\text { Adipocyte- } \\
\text { specific } N C o R^{-/-}\end{array}$ & $\begin{array}{l}\text { Increased obesity, improved } \\
\text { glucose metabolism, } \\
\text { decreased adipose tissue } \\
\text { inflammation on high-fat } \\
\text { diet. Increased expression of } \\
\text { PPAR- } \gamma \text { targets }\end{array}$ & PPARG & Li et al. (2011) & $\begin{array}{l}\text { Possibly: TRs regulate } \\
\text { adipogenesis, lipogenesis, } \\
\text { and lipolysis }\end{array}$ \\
\hline$N C o R \omega^{-1-}$ & $\begin{array}{l}\text { Pro-adipogenic: increased } \\
\text { obesity, improved } \\
\text { glucose metabolism, } \\
\text { hepatic steatosis on high-fat } \\
\text { diet }\end{array}$ & & $\begin{array}{l}\text { Goodson et al. } \\
\quad(2014)\end{array}$ & $\begin{array}{l}\text { Possibly: TRs regulate } \\
\text { adipogenesis, lipogenesis, } \\
\text { and lipolysis }\end{array}$ \\
\hline $\begin{array}{l}\text { Muscle-specific } \\
\text { NCo } R^{-/-}\end{array}$ & $\begin{array}{l}\text { Increased muscle mass and } \\
\text { exercise endurance, increased } \\
\text { oxidative metabolism }\end{array}$ & MEF2, PPARD, ERRs & $\begin{array}{l}\text { Yamamoto et al. } \\
\quad(2011)\end{array}$ & $\begin{array}{l}\text { Possibly: TH promotes fatty } \\
\text { acid oxidation }\end{array}$ \\
\hline $\begin{array}{l}\text { Liver-specific } \\
\text { Smrt-/- }\end{array}$ & $\begin{array}{l}\text { No major phenotype. Upregula- } \\
\text { tion of a few genes in retinoic } \\
\text { acid metabolism }\end{array}$ & RARs & $\begin{array}{l}\text { Sun et al. (2013); } \\
\text { Shimizu et al. } \\
(2015)\end{array}$ & Unlikely \\
\hline $\begin{array}{l}\text { Liver-specific } \\
\text { L-NCoR } \triangle I D \\
\text { Smrt-l- }\end{array}$ & $\begin{array}{l}\text { Cumulative effect on } \\
\text { derepression of TR target } \\
\text { genes and lipid synthesis and } \\
\text { sequestration. Mild hepatic } \\
\text { steatosis }\end{array}$ & TRs, LXRs & $\begin{array}{l}\text { Shimizu et al. } \\
\text { (2015) }\end{array}$ & \\
\hline \multirow[t]{2}{*}{ SmrtmRID } & $\begin{array}{l}\text { Increased fat mass, induction of } \\
\text { adipogenic genes, glucose } \\
\text { intolerance, reduced EE }\end{array}$ & TRs, PPARG & $\begin{array}{l}\text { Nofsinger et al. } \\
\text { (2010) }\end{array}$ & \\
\hline & $\begin{array}{l}\text { Impaired differentiation of type I } \\
\text { pneumocytes and respiratory } \\
\text { distress syndrome at birth }\end{array}$ & & Pei et al. (2011) & \\
\hline SmrtmRID1 & $\begin{array}{l}\text { Premature aging, metabolic } \\
\text { syndrome, reduced mitochon- } \\
\text { drial function. Obesity, } \\
\text { hepatosteatosis, insulin } \\
\text { resistance, and decreased EE on } \\
\text { high-fat diet }\end{array}$ & TRs, RARs, PPARs & $\begin{array}{l}\text { Fang et al. (2010); } \\
\text { Reilly et al. } \\
\text { (2010) }\end{array}$ & \\
\hline
\end{tabular}

http://jme.endocrinology-journals.org DOI: 10.1530/JME-15-0246
() 2016 Society for Endocrinology Printed in Great Britain
Published by Bioscientifica Ltd 
gluconeogenic enzymes by CCAAT/enhancer-binding protein (CEBPA) (Louet et al. 2010). It has also been reported that SrC1 is important for normal amino acid metabolism in the liver (Tannour-Louet et al. 2014).

When TH function was first assessed in these animals, overt resistance to TH was apparent at the level of HPT axis (Weiss et al. 1999). Intact Src1 function is also required for full $\mathrm{TH}$ sensitivity at least in some peripheral tissues as upregulation of positive $\mathrm{TH}$ targets in response to $\mathrm{T}_{3}$ is blunted in the liver of $\mathrm{Src}^{-/-}$mice. However, normal regulation of gene expression was observed in the heart (Vella et al. 2014). TR isoform-specific Src1 function was also assessed in compound Thra/Src1 and Thrb/Src1 knockout mice during $\mathrm{TH}$ deprivation and $\mathrm{TH}$ treatment. While lack of $5 r c 1$ alone has no effect on the growth rate or body weight, in the absence of either THRA or THRB, SRC1 becomes important for normal growth and weight gain, cooperatively regulating these parameters with each TR subtype in the absence of the other. SRC1 is also essential for maintaining normal heart rate, as its absence alone or combined with the knockout of either of TRs leads to significant decrease of the heart rate. Thra ${ }^{0 / 0} \mathrm{Src1}^{-/-}$mice have the most dramatic phenotypes in terms of heart rate, probably related to the fact that THRA is the predominant TR isoform in the heart (Sadow et al. 2003a). Overall, while metabolic effects of SRC1 have been attributed to signaling by various transcription factors, it is clear that SRC1 is necessary for TH signaling in peripheral tissues, suggesting that abnormal TR action may potentially play a role in metabolic phenotype found in $\mathrm{SrC}^{-/-}$animals.

\section{Src2 knockout mice}

In contrast to $\operatorname{Src} 1$ knockout mice, $\operatorname{Src} 2^{-/-}$animals display a favorable metabolic phenotype characterized by resistance to diet-induced obesity, increased glucose tolerance and insulin sensitivity, higher basal and stimulated lipolysis rates, and elevated $\mathrm{EE}$, at least partially due to a loss of its interactions with PPARG (Picard et al. 2002). Src2 deficiency also results in diminished hepatic glucose release due to the loss of co-activation of RORA that leads to decreased expression of glucose-6-phosphatase, resulting in hepatic glycogen accumulation similar to human genetic von Gierke's disease (Chopra et al. 2008). SRC2 also plays an important role in regulation of fatty acid absorption from the gut by activating expression of bile salt export pump through interactions with farnesoid $X$ receptor in response to reduced energy availability (Chopra et al. 2011). Recently, SRC2 was also identified as a co-activator for the two key transcription factors in the clock machinery that control circadian rhythms: BMAL1 (ARNTL) and CLOCK (Stashi et al. 2014a). Genomic recruitment of SRC2 in the liver was found to significantly overlap with ARNTL during the light phase (ZT2), and target expression of many metabolic genes, particularly those involved in glucose metabolism and fatty acid synthesis pathways.

\section{Src3 knockout mice}

SRC3 has been identified as a critical regulator of white adipocyte development. Src3-/- mouse embryonic fibroblasts (MEFs) are characterized by decreased adipogenic potential, and $5 r 3^{-/-}$animals have reduced body weight, decreased adipose tissue mass, and significantly decreased expression of PPARG2; a master regulator of adipogenesis. These effects are mediated by the loss of co-activation of CEBPA in the regulation of Pparg gene expression (Louet et al. 2006). In addition, Src3-/- mice are resistant to diet-induced obesity with improved glucose and lipid serum profiles, and increased EE due to activation of PPARGC1A in brown adipose tissue (Coste et al. 2008). SRC3 has also been implicated in control of long chain fatty acid metabolism by directly regulating carnitine/acyl-carnitine translocase (CACT or SLC25A20) gene expression. The phenotype of $\mathrm{SrC3}^{-/-}$ closely resembles phenotype of CACT genetic deficiency in humans, which presents with major metabolic dysregulation leading to hypoketonemia, hypoglycemia, hyperammonemia, and impaired neurologic, cardiac, and skeletal muscle performance (York et al. 2012). Consistent with human cases of CACT deficiency, Src3 knockout mice can be rescued by diets containing only short chain fatty acids. These results point to SRC3 as a key regulator of B-oxidation.

\section{NCORAID mice}

Mice that express a mutant co-repressor NcoR missing RID3 and RID2 (NCoRAID) have been used to address the physiologic role of NCoR-TR interactions (Fig. 1C) (Astapova et al. 2008). Analysis of hepatic gene expression in mice with liver-specific expression of NCoR $\triangle I D$ $(L-N C o R \Delta I D)$ clearly demonstrated that NCoR-TR interactions play a role in TR-mediated repression in vivo in hypothyroid state. Indeed, $16 \%$ of positive $\mathrm{TH}$ targets that are repressed in hypothyroid wt mice were significantly derepressed in $L-N C o R \Delta I D$ animals. This is

Published by Bioscientifica Ltd 
in agreement with recent genome-wide hepatic TR recruitment data suggesting that active repression that involves DNA binding by the unliganded TR and co-repressor complex may not occur at all TR-regulated genes: instead, $\mathrm{T}_{3}$-dependent recruitment of TR may be implicated in the regulation of a significant proportion of positive TR targets (Grontved et al. 2015, Ramadoss et al. 2013). At the same time, expression of less than $1 \%$ of negative $\mathrm{TH}$ targets (transcripts that were significantly upregulated in hypothyroid wt animals) was affected in L-NCoR $\triangle I D$ mice, showing limited, if any, role of NCoR in negative regulation by $\mathrm{TH}$ in the liver. Even more importantly, significant upregulation of a number of positive $\mathrm{TH}$ targets was observed in $L$-NCoR $\Delta I D$ livers in the euthyroid state. These results demonstrate that NCoR plays an important role in repression of positive TR targets during hypothyroidism and determines the sensitivity and responsiveness of gene expression to $\mathrm{TH}$ in euthyroid state.

Surprisingly, mice with global expression of NCoR $\triangle \mathrm{ID}$ (Astapova et al. 2011) are born at expected Mendelian ratios and appear phenotypically normal demonstrating that RID3 and RID2 are not required for normal development. Despite a 30\% decrease in circulating $\mathrm{TH}$ levels compared with wt littermates, NCoR $\triangle I D$ mice do not present with typical symptoms of hypothyroidism, as they grow normally, have normal body temperature and increased $\mathrm{EE}$, and either normal or increased expression of positive TR targets in peripheral tissues and the pituitary. These findings confirm that NCoR plays an important role in establishing sensitivity to $\mathrm{TH}$ in peripheral tissues.

\section{Deacetylase activation domain mutant mice}

Similar to global NCoRAID mice, animals bearing a mutation in HDAC3-activating domain of NcoR ( N-DADm mice) are viable and have no gross abnormalities (Alenghat et al. 2008). Elimination of DAD-mediated HDAC3 binding and activation leads to upregulation of Rev-ErbA (NR1D1) targets and disruption of normal circadian behavior. Alterations in the oscillatory expression patterns of several metabolic genes implicated in lipid metabolism in liver and adipose tissue in $N$-DADm mice lead to a favorable metabolic phenotype characterized by reduced fat mass, elevated $\mathrm{EE}$, and protection from diet-induced obesity and insulin resistance. Similar to NCoR $\triangle I D$ animals, euthyroid and hypothyroid $\mathrm{N}-\mathrm{DADm}$ mice showed derepression of several positive TH target genes in the liver (You et al. 2010). Moreover, N-DADm mice have a defect in TH-induced autophagy in the liver, which is a necessary step in TH-mediated increase in fatty acid mobilization and B-oxidation (Sinha et al. 2012). Overall, these data demonstrate that activation of HDAC3 by NCoR plays a crucial role in the regulation of circadian and metabolic physiology through various NRs including Rev-ErbA and TR isoforms.

Mice carrying DAD mutations in both NCoR and SMRT (NS-DADm) were also generated, and found, as expected, to have almost no detectable HDAC3 activity, increased histone acetylation around HDAC3 recruitment sites and reduced, but not completely abolished, genomic HDAC3 recruitment (You et al. 2013). Surprisingly, the phenotype of global NS-DADm mice was much less severe than Hdac3 knockout, which is embryonic lethal (Bhaskara et al. 2008), or even a liver-specific Hdac3 knockout (Feng et al. 2011, Knutson et al. 2008). Abrogation of HDAC3 activity in NS-DADm mice caused upregulation of fewer genes involved in lipid metabolism in the liver, and consistent with that, a much milder hepatic steatosis compared with hepatocyte-specific Hdac3 knockout. This suggests that while NCoR and SMRT DADs are necessary for HDAC3 activity and local histone deacetylation, these actions are not important for embryonic development (as demonstrated by comparison to germline knockouts of NCoR, Smrt, and Hdac3). It also appears that deacetylase activity contributes relatively modestly to the total effect of HDAC3 protein, as long as it can still be recruited to DNA by NCoR and SMRT, which was further confirmed in experiments using HDAC3 deacetylase-dead mutants and liver-specific NCoR knockout mice (Sun et al. 2013).

\section{Liver-specific NCoR knockout}

In agreement with observations made in mutant NCoR knock-in animal models (Alenghat et al. 2008, Astapova et al. 2008), liver-specific NCoR knockout mice demonstrated derepression of genes involved in NADPH and lipid synthesis and sequestration, which are known to be controlled by LXRs, TRs, and Rev-ErbA. However, these mice develop significant hepatosteatosis, similar to what is seen in liver-specific Hdac3 knockout mice, which was not present in the knock-in animals and is supposedly due to the complete loss of genomic HDAC3 recruitment (Sun et al. 2013). Paradoxically, expression of fatty acid oxidation and mitochondrial function genes, which are under transcriptional control of PPARs and estrogen-related receptors (ERRs), was also elevated in liver-specific NCoR knockout mice (Jo et al. 2015). Interestingly, affinity of NCoR to different groups of

Published by Bioscientifica Ltd. 
NRs may be manipulated in the liver by insulin-induced protein kinase B/Akt-mediated phosphorylation on S1460. Phosphorylation at this site results in diminished binding affinity of NCoR to LXRA and selectively derepresses its target genes resulting in increased lipid synthesis. At the same time, phosphorylated NCoR binds PPARA and estrogen related receptor alpha (ERRa or ESRRA) with higher affinity to attenuate expression of oxidative metabolism genes in the liver when insulin signaling is activated, for example, in the fed state. This insulin-dependent phosphorylation allows for a switch of recruitment of NCoR between different groups of NRs and provides a mechanism for specific modulation of NR signaling depending on physiological conditions (fed vs fasted). While the effect of the S1460 phosphorylation on NCoR-TR interactions has not been studied yet, it could potentially also have important ramifications for TR signaling, as TH has been shown in different experimental paradigms to promote both lipid synthesis and fatty acid oxidation in the liver (Feng et al. 2000, Flores-Morales et al. 2002, Jackson-Hayes et al. 2003, Oppenheimer et al. 1991).

\section{Liver-specific Smrt knockout}

Surprisingly, hepatocyte-specific deletion of Smrt revealed that SMRT alone, in contrast to NCoR, plays no role in the regulation of positive or negative $\mathrm{TH}$ targets or the lipogenic pathway in general (Shimizu et al. 2015, Sun et al. 2013). At the same time, SMRT appears to be important for RAR signaling and regulation of RAR target genes (Shimizu et al. 2015), confirming the in vitro data on preferential interactions between specific RIDs and NRs (Cohen et al. 2001, Cohen et al. 2000, Makowski et al. 2003, Webb et al. 2000). Interestingly, the combination of a hepatic SMRT knockout and L-NCoR $\Delta$ ID expression demonstrated that SMRT works coordinately with NCoR to regulate lipid synthesis and sequestration, and the regulation of some of TH targets. While SMRT knockout alone has no effect on expression of genes implicated in these pathways, the combination of the two results in further upregulation of these genes compared with $L$-NCoR $\triangle I D$ mice, and significant triglyceride accumulation in the liver. This suggests that a certain hierarchy in the recruitment of co-repressors competing for the same binding site on the TRs, and potentially other NRs, exists: NCoR is clearly the principal co-repressor for TRs and the lipogenic pathway in the liver in general, and is normally recruited to these genes, which is why removal of SMRT alone has no effect on their expression.
When NCoR is absent, SMRT can only partially substitute its function, and moderate activation of the gene expression can be seen. Removal of both co-repressors results in a full derepression of the pathway leading to a phenotype with marked lipid accumulation. These effects are likely mediated by different NRs including TRs, LXR, and Rev-ErbA. These experiments again confirmed that neither NCoR nor SMRT plays a role in the negative regulation by ligand-bound TRs in the liver.

\section{NCoR in adipose tissue: adipocyte-specific and NCoR $\omega$ knockout}

Adipocyte-specific deletion of NCoR has shown that this CoR represses PPARG signaling pathway in adipocytes (Li et al. 2011). Adipocyte-specific NCoR knockout mice fed high-fat diet demonstrate phenotypic resemblance to animals treated with PPARG agonists, which includes obesity, improved whole-body glucose tolerance, and changes in adipocyte morphology and function, diminished macrophage infiltration, and inflammation. Indeed, PPARG target genes were upregulated in adipose tissue of NCoR knockout animals, and these mice were refractory to further PPARG-stimulation with rosiglitazone, in agreement with the notion that deletion of $\mathrm{NCOR}$ increases sensitivity to endogenous PPARG ligands.

It has been shown that adipogenesis in mice is associated with a switch in co-repressor splicing from NCoR $\omega$ carrying all three RID domains, which represses adipogenesis, to NCoR $\delta$ where only RID2 and RID1 are present, which appears to support a pro-adipogenic program (Goodson et al. 2011). Consistent with the adipocyte-specific NCoR knockout phenotype, whole-body expression of the pro-adipogenic

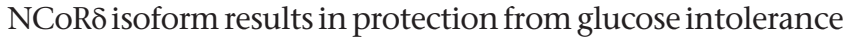
despite increased weight gain and adiposity, as well as hepatic steatosis on a high-fat diet (Goodson et al. 2014). These results indicate that adipocyte-specific change in $\mathrm{NCoR}$ splicing during development helps drive normal adipocyte differentiation, while the presence of the full-length NCoR splice variant prevents excessive fat accumulation in the liver. They also suggest that since $N C o R \omega^{-/}$is missing RID3, which is critical for NCoR-TR interactions, TR signaling is likely to contribute to the phenotype of these and, possibly, adipose-specific NCoR knockout animals in addition to PPARG.

\section{Muscle-specific NCoR knockout}

Muscle-specific deletion of $N C o R$ has demonstrated that it plays a role in repression of fatty acid oxidation in

Published by Bioscientifica Ltd. 
the muscle (Yamamoto et al. 2011). The lack of NCoR expression in the muscle results in higher mitochondrial activity and number and overall higher oxidative capacity leading to improved exercise endurance. These effects were attributed to increased activity of transcription factors MEF2, PPARD, and ERR isoforms, but no observations related to TR activity were made, even though $\mathrm{TH}$ is also known to promote fatty acid oxidation. It was also demonstrated that NCoR expression is decreased in physiological conditions that are associated with an increase in fatty acid oxidation, such as aging, fasting, high-fat feeding, or after endurance exercise.

\section{SMRT receptor interacting domain mutant mice (SmrtmRID and SmrtmRID1)}

SmrtmRID mouse model bears mutations in two SMRT RIDs (RID1 and RID2) (Fig. 1C), which abolish its interactions with RAR, TR, and PPAR isoforms (Nofsinger et al. 2008). SmrtmRID mice are born at expected ratios, but have slightly reduced viability on a mixed C57BL/6-Sv129 genetic background. Adult animals display a number of metabolic disturbances: significantly increased adiposity with reduced body weight, decreased EE, and RER, increased basal hepatic glucose production, and diminished insulin-stimulated glucose disposal leading to elevated fasting glucose and glucose intolerance. MEFs isolated from $S m r^{m R I D}$ mice demonstrate increased PPARG signaling and adipogenic potential suggesting that SMRT, by repressing signaling by PPARG and potentially other NRs, plays an important role in determining the adipogenic set point. Hypothyroid SmrtmRID mice demonstrate significant derepression of some TH target genes in the liver and improvement of hypothyroidisminduced hypercholesterolemia, indicating that SMRT plays a role in repression of positive TR targets in the absence of hormone. This is contrary to what was seen in the liver-specific Smrt knockout (Shimizu et al. 2015), and whether the differences are due to the whole-body vs liver-specific deletion or the ability of mutant SMRTmRID to still bind HDAC3 and other components of the repression machinery remains to be clarified.

Interestingly, on a pure C57BL/6 background, close to $99 \%$ of $S m r^{m R I D}$ pups die due to a defect in the development of type 1 pneumocytes that leads to previously unknown respiratory distress syndrome (Pei et al. 2011). The Smrt ${ }^{m R I D}$ pups could be rescued by treating the pregnant dams with antithyroid drugs propylthiouracil or methimazole, which led to a complete restoration of expression of type 1 pneumocyte markers and normal survival. It has been determined that the lethal phenotype is due to downregulation of expression of a negative $\mathrm{TH}$ target Krüppel-like factor 2 (Klf2) in neonatal SMRTmRID lungs. These observations demonstrate that normal development of neonatal lung and animal survival are dependent on expression of transcription factor KLF2, which is activated by TR through its interactions with SMRT in a ligandindependent manner.

SmrtmRID1 mice carry a mutation only in RID1 (Fig. 1C), which changes the interaction patterns, so that while RID1-mediated interactions are abolished, the interactions mediated by the most C-terminal RID (RID1 in Fig. 1) are enhanced leading to increased repression by PPARs and potentially some other NRs (Fang et al. 2010, Reilly et al. 2010). Smrt ${ }^{m R I D 1}$ mice have decreased lifespan accompanied by premature aging and related metabolic disease. They are also characterized by repression of genes in the oxidative metabolism pathway and reduced mitochondrial function, potentially due to enhanced repression of these genes by PPARs. Similar to SmrtmRID mice, these animals are more susceptible to diet-induced obesity and development of insulin resistance, and have decreased RER. However, unlike SmrtmRID mice they are refractory to glucose-lowering effects of thiazolidinediones and 5-amino-4-imidazolecarboxamide ribose and also display marked hepatic steatosis. The common features of these two SMRT mutant mouse strain phenotypes are likely due to the derepression of NRs interacting with the similarly mutated RID, while the differences are the result of increased repression through PPAR isoforms in SmrtmRID1 animals.

Overall, multiple animal models discussed above have demonstrated that in peripheral tissues co-repressors attenuate expression of positive TR and other NR target genes both in the absence and presence of ligand, while co-activators are necessary for full activation of positively regulated genes in response to the hormonal signal. However, possible role of co-regulators in liganddependent negative regulation remains much less clear.

\section{Role of co-regulators in the function of HPT axis and RTH}

The HPT axis has developed as an elegant feedback system that controls circulating TH levels. In this system, elevated concentrations of $\mathrm{TH}$ negatively regulate production of both TRH in the hypothalamus and TSH in the pituitary, while a drop in serum $\mathrm{TH}$ would induce synthesis and secretion of both TRH and TSH (Chiamolera \& Wondisford 2009). This regulation is highly sensitive,

Published by Bioscientifica Ltd. 
so that circulating TSH level is the most common TH function test in humans. Hormone-bound TRs potently represses both $T R H$ gene expression in the paraventricular nucleus of hypothalamus and expression of TSH subunits, encoded by CGA and TSHB genes, in the pituitary, making these genes a classic example of negative TH targets, but exact molecular mechanisms underlying this hormonedependent negative regulation remain unclear (Abel et al. 2001, Abel et al. 1999, Hollenberg et al. 1995, Sugrue et al. 2010, Wood et al. 1989).

Classic RTH is an inherited syndrome characterized by various degrees of peripheral and central hyposensitivity to $\mathrm{TH}$, such that high serum levels of free $\mathrm{T}_{4}$ and $\mathrm{T}_{3}$ are accompanied by inappropriately elevated or normal TSH, lack of most usual symptoms of thyrotoxicosis and often a goiter (Beck-Peccoz \& Chatterjee 1994, Refetoff et al. 1967, Refetoff et al. 1993). This type of RTH is most commonly caused by mutations in the THRB gene that have been identified in affected subjects belonging to more than 450 families. In majority of cases, peripheral hyposensitivity to $\mathrm{TH}$ is compensated for by high circulating TH levels, with some variability between individuals. Thyroid status also varies between different tissues, most likely as a result of tissue-specific expression of THRA vs THRB, leading to a simultaneous presentation of symptoms of hypo- and hyperthyroidism (lack of negative feedback in HPT axis and delayed growth vs tachycardia and hyperactivity) (Dumitrescu \& Refetoff 2013). Most mutations found in subjects with classic RTH are located in the activation function-2 (AF-2) and reduce its affinity for the hormone. Such mutants interfere with the function of the wt THRB in a dominant-negative manner (Adams et al. 1994, Hayashi et al. 1995). Some mutant THRBs were found to have impaired interaction with one of the cofactors involved in the regulation of $\mathrm{TH}$ action (Collingwood et al. 1997, Collingwood et al. 1998, Liu et al. 1998, Tagami \& Jameson 1998, Yoh et al. 1997).

Recently, a few families with mutations in THRA have also been identified, with clinical presentations very different from classic THRB RTH. The affected individuals have slightly abnormal thyroid function tests with low to normal free $\mathrm{T}_{4}$, slightly elevated free $\mathrm{T}_{3}$, reduced $\mathrm{rT}_{3}$, and normal TSH levels, but display clear phenotypic characteristics of hypothyroidism with growth and developmental retardation, skeletal dysplasia, marked constipation (diarrhea in one case), and cognitive impairment. Identified mutations in THRA gene led to expression of either a truncated THRA completely unable to bind $\mathrm{T}_{3}$ or mutations decreasing affinity to $\mathrm{T}_{3}$ and transcriptional activity showing dominant-negative features (Bochukova et al. 2012, Espiard et al. 2015, Moran et al. 2014, Moran et al. 2013, Tylki-Szymanska et al. 2015, van Mullem et al. 2012). Cases of RTH in the absence of mutations in the THRB or THRA genes were also identified suggesting that mutations in co-regulator protein might be involved; however, human subjects with this type of RTH are yet to be identified (Reutrakul et al. 2000, Weiss et al. 1996).

Mouse models carrying mutations in Thrb gene found in patients with RTH, such as ThrbPV and Thrb ${ }^{T 337 D}$, were generated and found to recapitulate classic dominantly inherited RTH (Hashimoto et al. 2001, Kaneshige et al. 2000). Mice expressing ThrbE457A mutation that abolishes co-activator binding and homozygous Thrb knockout animals also demonstrate various degrees of resistance to TH (Ortiga-Carvalho et al. 2005), reviewed in Flamant and Samarut (2003). Thra knock-in mouse models carrying mutations analogous to those found in patients with THRB RTH were generated before identification of patients with THRA gene mutations (Thra ${ }^{P V}$, Thra ${ }^{R 384 C}$, Thra ${ }^{L 400 R}$, Thra ${ }^{P 398 H}$, Thra ${ }^{R 384 C}$ ) and display varying phenotypes, with some of them being similar to patients with THRA RTH (Kaneshige et al. 2001, Liu et al. 2003, Quignodon et al. 2007, Tinnikov et al. 2002), reviewed in van Mullem et al. (2014) and Vennstrom et al. (2008). It has been suggested that while inability to recruit co-activators, such as SRC1, would worsen THRB-mediated RTH, loss of co-repressor binding to TRs would at least partially rescue symptoms of RTH, which phenotypically present as hypothyroidism, with the effect on the hyperthyroid symptoms depending on the drop of circulating TH. Lack of co-repressor recruitment in the THRA-mediated RTH may potentially have an even bigger effect, as in the presence of normal circulating $\mathrm{TH}$ levels (as opposed to high in THRB RTH), ability of TR to recruit co-repressors should be higher. Data regarding the role of co-regulators in the function of HPT axis and presentation of RTH obtained using genetically modified mouse models, are summarized in Table 2 .

\section{Co-activator knockout models}

The $\operatorname{Src} 1$ knockout model demonstrated for the first time in vivo that SRC1 is necessary for normal function of the HPT axis (Weiss et al. 1999). Mice deficient in Src1 display RTH with phenotypic presentation similar to classic human RTH: elevated serum TSH levels accompanied by high serum free $\mathrm{T}_{4}$ and $\mathrm{T}_{3}$. These mice demonstrate reduced sensitivity to TH at thyrotrope level, as suppression of $\mathrm{TSH}$ by $\mathrm{T}_{3}$ is severely blunted compared with wt animals,

Published by Bioscientifica Ltd 
Table 2 Summary of phenotypes of mouse models discussed in the review as related to regulation of HPT axis.

\begin{tabular}{|c|c|}
\hline Mouse model & Phenotype \\
\hline Src1-1- (Ncoa1) & $\begin{array}{l}\text { RTH similar to TRB RTH: high } \mathrm{T}_{3}, \mathrm{~T}_{4} \text {, and unsuppressible TSH } \\
\text { Worsening of Trb }\end{array}$ \\
\hline $\operatorname{Src2} 2^{-1-}($ Ncoa 2$)$ & No phenotype at the level of HPT axis \\
\hline Src1-I-/Src2-I- & Worsening of RTH compared with Src1-/- alone \\
\hline$N C O R \Delta I D(N C O R 1)$ & $\begin{array}{l}\text { Decreased circulating } \mathrm{T}_{4} \text { and } \mathrm{T}_{3} \text {, normal TSH; normal response to } \\
\text { dynamic changes in } \mathrm{TH} \text { levels; decreased responsiveness of the } \\
\text { thyroid to TSH } \\
\text { Partial improvement of RTH in Thrb } \\
P V /+ \text { and } T h r a 1^{P V /+} \text { models }\end{array}$ \\
\hline Postnatal NCoRAID & $\begin{array}{l}\text { Decreased circulating } \mathrm{T}_{4} \text { and } \mathrm{T}_{3} \text {, normal TSH similar to global } \\
N C O R \Delta I D \text { animals }\end{array}$ \\
\hline $\begin{array}{l}\text { Pituitary-specific } \\
\text { Cga-NCoRAID }\end{array}$ & $\begin{array}{l}\text { Decreased circulating } \mathrm{T}_{4}, \mathrm{~T}_{3} \text {, and TSH. Blunted upregulation of TSH } \\
\text { during hypothyroidism }\end{array}$ \\
\hline$N C O R-D A D m$ & $\begin{array}{l}\text { Normal } \mathrm{T}_{4} \text { and } \mathrm{T}_{3} \text { levels, elevated TSH; normal TSH response to } \\
\text { dynamic changes in TH levels }\end{array}$ \\
\hline $\begin{array}{l}\text { SmrtmRID } \\
\text { (NCoR2) }\end{array}$ & Slightly reduced $\mathrm{T}_{4}$ on C57/BL6 background \\
\hline Postnatal Smrt ${ }^{-1-}$ & No effect on HPT axis \\
\hline NCoR $\Delta I D \mathrm{Src}^{-/-}$ & Normalized HPT function \\
\hline
\end{tabular}

\author{
References \\ Weiss et al. (1999) \\ Kamiya et al. (2003); Alonso et al. (2009) \\ Weiss et al. (2002) \\ Weiss et al. (2002) \\ Astapova et al. (2011)
}

Fozatti et al. (2011); Fozatti et al. (2013)

Costa-e-Sousa et al. (2012)

Costa-e-Sousa et al. (2012)

You et al. (2010)

Pei et al. (2011)

Shimizu et al. (2015)

Vella et al. (2014) both in baseline 'euthyroid' and in hypothyroid state. This suggests that SRC1 behaves as a co-repressor in vivo when it interacts with a gene that is negatively regulated by $\mathrm{TH}$ as was observed previously in vitro (Tagami et al. 1997). The elevated circulating $\mathrm{TH}$ in Scr1-/- animals appears to be driven by TSH, as suppression of TSH by the administration of supraphysiological doses of $T_{3}$ results in reduction of endogenous $T_{4}$. Notably, the absence of Src1 did not affect the full ligand-independent stimulation of TSH, suggesting that other co-regulators may play a co-activator role in this case. Overall, Src1-/mice demonstrate RTH phenotype at the level of HPT axis comparable to the Thrb-null mice, but less severe than the TH resistance present in total Thrb or compound Thrb and Thra-deficient animals (Takeuchi et al. 2002, Weiss et al. 1999).

The specific role of SRC1 in activation of TH-regulated gene transcription by different TR isoforms in the pituitary was also assessed using compound Src1/Trb- and Src1/ Thra-deficient mice (Sadow et al. 2003b). Interestingly, Src1/Thrb mice have more severe TH resistance than either of the single knockouts, implying that SRC1 has a role in TH action independent of THRB. At the same time while Thra knockout mice are hypersensitive to $\mathrm{TH}$ action at the thyrotrope level, Src1/Thra-deficient mice demonstrate $\mathrm{TH}$ resistance presented as inefficient suppression of TSH. Consistent with previous observations ( $\mathrm{Xu}$ et al. 1998), Src1 deficiency was found to lead to elevation of expression of $\operatorname{Src} 2$ and -3 in pituitary, which could be a mechanism of partial compensation for Src1. This is also supported by the data obtained in compound Src1 and -2 knockout mice (Weiss et al. 2002). While Src1-/- mice are resistant to $\mathrm{TH}, \mathrm{SrC}_{2}{ }^{-/-}, \mathrm{SrC} 2^{+/-}$, and $\operatorname{Src} 1^{+/-}$mice displayed normal thyroid function tests. Surprisingly, double heterozygous Src1/Src2 mice presented with a RTH phenotype similar to the Src1 homozygous knockouts. Deletion of both Src1 and -2 resulted in marked increases of serum TH and TSH concentrations, showing dramatic resistance to $\mathrm{TH}$, surpassing that of total Thrb-/- mouse model. This demonstrates partial functional redundancy of SRC1 and -2 in the regulation of HPT axis by TH. However, in this context, SRC1 is clearly the preferred co-activator for TRs, while SRC2 becomes important only when the levels SRC1 are decreased or abrogated, which is also associated with an increase in SRC2 as discussed above. These data clearly demonstrate that co-activator recruitment to TRs is crucial for normal regulation of HPT axis.

\section{Co-repressor-deficient models}

Mice with global expression of NCoR $\Delta \mathrm{ID}$ generated through germline mutation were used to address the potential role of co-repressors in the regulation of HPT axis in vivo (Astapova et al. 2011). NCoRAID mice have low circulating $\mathrm{T}_{4}$ and $\mathrm{T}_{3}$ levels with inappropriately normal serum TSH and expression of TSH subunit mRNA in the pituitary, suggestive of central hypothyroidism. However, NCoR ID mice do not appear hypothyroid due to enhanced sensitivity to $\mathrm{TH}$ in peripheral tissues. At the same time, the sensitivity of HPT axis is not altered, as changes in circulating $\mathrm{TH}$ produce normal response in TSH levels and expression. Interestingly, these animals

Published by Bioscientifica Ltd. 
have reduced intrathyroidal levels of free $T_{4}$ and $T_{3}$, and the ability of the thyroid gland to secrete $\mathrm{TH}$ in response to TSH stimulation is significantly attenuated. Therefore, disruption of NCoR-TR interactions leads to increased sensitivity to $\mathrm{TH}$ in peripheral tissues, which is compensated for by a reset HPT axis where the thyroid produces less $\mathrm{TH}$, while pituitary and possibly hypothalamus recognize lower $\mathrm{TH}$ levels as normal. Importantly, mice where global expression of NCoR $\Delta$ ID was induced in adulthood using an inducible ubiquitous Cre recombinase, demonstrated an identical phenotype, confirming that the alterations in HPT axis are not a result of a developmental defect (Costae-Sousa et al. 2012). Moreover, expression of NCoR $\Delta I D$ specifically in the pituitary using a Cre recombinase driven by the glycoprotein A-subunit promoter led to a phenotype characterized by low TH levels and decreased TSH production. Remarkably, the rise of TSH during hypothyroidism was also blunted in these animals, in contrast with $\operatorname{Src1}$ knockout mice. While serum $\mathrm{T}_{4}$ concentrations were slightly reduced in Smrt ${ }^{\text {mRID }}$ mice on C57/BL6 background (Pei et al. 2011), postnatal global ablation of SMRT had no effect on circulating $\mathrm{T}_{4}$ levels or TSH subunit expression in the pituitary, confirming that similarly to the liver, specificity of co-repressor recruitment exists in HPT axis, and NCoR is the preferred TR co-repressor (Shimizu et al. 2015).

A somewhat different phenotype related to dysregulation of HPT axis was found in N-DADm mice (You et al. 2010). These mice were characterized by significantly elevated serum TSH and TSH subunit expression in the presence of normal serum $\mathrm{T}_{4}$ and $\mathrm{T}_{3}$. Manipulations with circulating TH levels, produced normal response in terms of serum TSH; however, pituitary expression of TSH and type 2 deiodinase remained modestly but significantly elevated in all conditions, suggesting that in these animals HPT axis is reset to recognize normal TH levels as low, opposite to what is seen in NCoR $\triangle I D$ mice. This discrepancy is potentially due to the fact that while NCoR $\Delta$ ID simply does not bind TRs potentially increasing their ability to recruit other cofactors, in N-DADm mice NCoR does not activate HDAC3, but is still recruited competing with co-activators for the binding site.

As Src1-deficient mice are resistant to the actions of $\mathrm{TH}$ but the disruption of interactions between TR and NCoR in N-CoR $\triangle I D$ mice leads to increased sensitivity to $\mathrm{TH}$, it was hypothesized that $\mathrm{RTH}$ in $\mathrm{Src1}^{-/-}$mice is caused by unopposed co-repressor action. Remarkably, when Src1-/- were crossed with $\mathrm{N}$-CoR $\Delta I D$ animals, the resulting compound knockout mice had normal circulating $\mathrm{TH}$ and TSH levels and normal ability to suppress TSH in response to $\mathrm{T}_{3}$ treatment, thus demonstrating reversal of resistance present in Src1-deficient mice (Vella et al. 2014). Additionally, $\mathrm{T}_{3}$-mediated upregulation of positive TR target genes in the liver, which is blunted in $\mathrm{SrC1}^{-/-}$mice, was restored in NCoRAID $\mathrm{SrC}^{-1-}$ animals. Interestingly, expression of Src2 and recruitment of SRC2 to promoters of positive TR target genes was significantly increased in NCoRAID Src1. This again suggests a hierarchy in the recruitment of co-regulators to TR: in the absence of SRC1, high affinity binding of NCoR prevents recruitment of SRC2 co-activator even in the presence of ligand. However, removal of NCoR allows to re-establish the co-regulator balance.

\section{Role of SRCs in other RTH models}

Inability to recruit co-activators by mutant THRB is thought to play a role in the development of RTH. In $T_{h r} b^{P V}$ mutant mice, a model of RTH with a knock-in mutation in the Thrb locus that completely abolishes $\mathrm{T}_{3}$ binding to THRB (Kaneshige et al. 2000), lack of Src1 leads to a worsening of the HPT axis dysregulation and growth abnormalities in $\mathrm{Thrb}^{P V /+}$ mice but not in $\mathrm{Thrb}^{P V /}$ $P V$ mice. In $T r b^{P V / P V}$ animals, $\operatorname{Src} 1$ deficiency intensified the pathological progression of thyroid follicular cells to papillary hyperplasia. Lack of Src1 did not affect serum cholesterol levels in either $T h r b^{P V /+}$ or $T h r b^{P V / P V}$ mice, but led to dysregulated expression of several $\mathrm{T}_{3}$ target genes in the pituitary and liver (Kamiya et al. 2003).

Mice expressing THRB with E457A mutation in AF-2 that does not affect ligand binding but completely abolishes recruitment of co-activators to LBD also demonstrate profound RTH phenotype at peripheral tissues and HPT axis (Ortiga-Carvalho et al. 2005). Surprisingly, disruption of $\operatorname{Src1}$ in the Thrb ${ }^{E 457 A / E 457 A}$ mice worsened the degree of resistance to $\mathrm{TH}$, resulting in increased serum $\mathrm{T}_{4}$ and TSH at baseline. During TH deprivation, simultaneous disruption of AF-2 and Src1 resulted in a blunted TSH rise, only $50 \%$ of what was seen in $T h r b^{E 457 A}$ mutant alone, suggesting that $\operatorname{Src} 1$ can interact with THRB outside of the AF-2 domain and, contrary to previous conclusions from $\operatorname{Src} 1$ knockout mice, is necessary for activation of HPT axis during TH deprivation, likely through interaction with another region of the THRA or THRB. At the same time, liganddependent repression of TSH requires recruitment of SRC1 to AF-2 (Alonso et al. 2009). These data clearly demonstrate that disruption of co-activator recruitment to TRs contributes to dysregulation of HPT axis present in RTH by a variety of different mechanisms.

Published by Bioscientifica Ltd. 


\section{Role of co-repressors in RTH}

Constitutive recruitment of co-repressors by the mutant TR has been proposed to be one of the molecular mechanisms underlying RTH. Availability of NCoRAID mice provided an opportunity to test this hypothesis in vivo. The absence of TR-NCoR interactions in Thrb ${ }^{P V} / \mathrm{NCoR} \Delta I D$ animals results in a moderate but significant decrease in circulating $\mathrm{T}_{4}$, $\mathrm{T}_{3}$, and TSH levels and TSH subunit expression, especially in the presence of only one mutant PV allele (a situation more similar to human RTH) (Fozzatti et al. 2011). At peripheral level, weight loss, severe thyroid hyperplasia, and repression of a number of hepatic TR target genes were also reversed. Furthermore, expression of NCoR $\Delta$ ID could partially ameliorate abnormalities in the HPT axis of Thra1 ${ }^{P V /+}$ mice that carry the dominant-negative frameshift PV mutation and display a phenotype similar to that found in humans with mutations in Thra gene (Fozzatti et al. 2013). NCoRAID/Thra ${ }^{\text {PV/+ }}$ animals also displayed improvement in severe growth retardation, infertility, delayed bone development, and impaired adipogenesis. Thus, aberrant recruitment of NCoR by mutant TRs may contribute to clinical presentation of both THRB and THRA RTH. It appears that abolishing NCoR-TR interaction is effective in terms of correcting the peripheral symptoms of hypothyroidism in both types of RTH, but less effective in correcting the resistance at the level of HPT axis seen in TRB RTH. Therefore, it is unlikely to have a positive effect on clinical presentation of hyperthyroid symptoms seen in certain tissues in patients with classic RTH.

\section{Lessons from genome-wide analysis of TR chromatin recruitment}

The bimodal switch model of TR-mediated transcriptional regulation is based on the primarily nuclear localization of TRs (as opposed to sex steroid receptors) and assumption that TR binding to response elements in the target genes is not affected by the presence of TH (Baumann et al. 2001, Perlman et al. 1982, Wong et al. 1995, Xu et al. 1999). While preferred TR-binding sites have been established in vitro, and a number of TREs have been identified in some target genes, a comprehensive analysis of TR-binding patterns on the genome-wide level has not been performed until recently (Chatterjee et al. 1989, Glass et al. 1987, Glass et al. 1988, Petty et al. 1990, Zilz et al. 1990).

In two studies, a genome-wide recruitment of tagged overexpressed TRs was assessed in neural and hepatic cell lines using chromatin affinity precipitation (ChAP)-seq (Ayers et al. 2014, Chatonnet et al. 2013). Chatonnet et al. compared THRA and THRB transcriptomes and cistromes in neural cell lines, where $T_{3}$ responsiveness was restored by expression of tagged version of either TR isoform, while Ayers et al. (2014) studied THRB genome-wide binding in hepatocellular carcinoma cell line. Both studies found significant enrichment for TR-binding sites in the proximity of genes positively regulated by $\mathrm{T}_{3}$. In contrast, no significant enrichment of TR binding was seen at negatively regulated genes, thus providing no statistical confirmation for negative regulation by liganded TRs. TRE half-sites and classical TREs were present at many peaks, and a direct repeat of a NR-binding motif AGGTCA with a 4 nucleotide spacer (DR-\$) was established as the consensus TR-binding site for both THRA and THRB in neural cells as expected. It was also demonstrated that genomic THRA and THRB binding had not only some overlap, but also had a great number of unique targets.

Two other studies have investigated genomic recruitment of THRB1 in the liver under hypo- and hyperthyroid conditions in vivo using different approaches: i) using biotin-tagged THRB1 overexpressed in mouse liver by adenoviral delivery to allow for affinity precipitation and ChAP-seq (Ramadoss et al. 2013) and ii) using a mouse monoclonal THRB-specific antibody to assess recruitment of endogenous THRB 1 by chromatin immunoprecipitation (ChIP)-seq (Grontved et al. 2015).

Ramadoss et al. (2013) reported a high number of TR-binding peaks $(20,939$ peaks in PTU-treated and 15,723 in $\mathrm{T}_{3}$-treated livers), with most of the peaks located within the genes. Interestingly, at many sites recruitment of THRB1 was affected by the presence of $T_{3}$. At most sites where TR occupancy changed depending on the presence of $\mathrm{T}_{3}$ TR binding was increased by $\mathrm{T}_{3}(80 \%$ of all changed peaks). These sites were located farther away from transcription start sites (TSS) of known genes, suggesting that hormone-induced changes in THRB1 binding are more likely to occur at distal enhancer elements. Only $2 \%$ of $\mathrm{T}_{3}$-sensitive peaks were located within the proximal promoters (TSS to $-500 \mathrm{bp}$ ), while $17 \%$ of all peaks identified in hypothyroid and $7 \%$ of all peaks identified in hyperthyroid states were present in that region. Moreover, $\mathrm{T}_{3}$-induced peaks showed less overlap with DNase hypersensitivity peaks (data obtained from mouse ENCODE project), compared with invariant or peaks that were decreased with $\mathrm{T}_{3}$ treatment, suggesting that $\mathrm{T}_{3}$ may promote binding of THRB1 to less accessible chromatin regions and potentially induce chromatin remodeling. Overall, the changes in THRB1 binding correlated with changes in the expression of nearby genes in the same direction; however, some

Published by Bioscientifica Ltd. 
genes were identified where the expression was regulated in the opposite direction. Therefore, it is possible that diminished THRB1 binding in the presence of $\mathrm{T}_{3}$ may be the mechanism of negative regulation for some genes. Similar to the findings in the cell lines, significantly more genes upregulated by $\mathrm{T}_{3}$ treatment were found to have associated THRB-binding sites (73\%) as compared with downregulated genes (40\%), suggesting that negative regulation by $\mathrm{T}_{3}$ may be largely indirect. However, the association of negatively regulated genes with THRB1 binding was still significant, thus implying that liganded THRB1 can in some instances function as a repressor. Motif analysis of all THRB1-binding sites has identified DR-4 as the most enriched element, consistent with previous reports. Surprisingly, while DR-4 was also the most represented motif in the peaks where TR binding was increased in the presence of $\mathrm{T}_{3}$ and associated with elevated gene expression, DR-0 was enriched in the peaks decreased with $T_{3}$ treatment and associated with diminished gene expression. This provides an insight into the potential mechanisms as to how TR may mediate positive and negative regulation by employing differential binding at unique target sites.

Finally, Grontved et al. (2015) combined THRB1 ChIPseq approach with DNaseI hypersensitivity assay to assess potential chromatin remodeling events associated with $\mathrm{T}_{3}$ signaling. Much fewer TR-binding sites were identified in this study compared with the study by Ramadoss et al. (2013), which could be due to the differences in the abundance of endogenous THRB1 vs overexpressed and/or relatively low avidity of the monoclonal TR antibody used in this study. The obtained data suggest a model, where $T_{3}$ greatly increases THRB1 recruitment to chromatin with 864 TR-binding sites identified in hypothyroid and 2186 in hyperthyroid conditions, where majority of the TR-independent peaks overlapped with those found only in the presence of $\mathrm{T}_{3}$. De novo motif analysis found enrichment for the DR-4 TRE in 60\% of hormone-independent TR-binding peaks and $42 \%$ of $\mathrm{T}_{3}$-facilitated peaks. Interestingly, less than $20 \%$ of unique hypothyroid peaks contained TREs, suggesting that these peaks may result from indirect TR binding. Overall, $60 \%$ of $\mathrm{T}_{3}$-induced genes were found to have at least one TR-binding peak within $50 \mathrm{~kb}$ of TSS, while genes negatively regulated by $\mathrm{T}_{3}$ show little enrichment, suggesting that $\mathrm{T}_{3}$-dependent repression may be largely mediated by indirect mechanisms. $\mathrm{T}_{3}$ was found to induce robust changes in chromatin accessibility. In general, $92 \%$ of identified TR-binding sites were localized within the accessible chromatin (either unchanged or remodeled upon $\mathrm{T}_{3}$ treatment), with almost no binding found within the DNase hypersensitive sites (DHS) reduced by $\mathrm{T}_{3}$ treatment. Most interestingly, $10 \%$ of $\mathrm{T}_{3}$-induced TR peaks were localized in the regions with DHS formed de novo upon $\mathrm{T}_{3}$ treatment, suggesting that TRs can induce chromatin remodeling in a liganddependent manner. This demonstrates that TR can be recruited to chromatin in different scenarios, including hormone-independent binding of unliganded TR to open chromatin and ligand-induced TR recruitment to previously inaccessible chromatin, leaving a question as to how TR discriminates between these types of binding sites, especially in hypothyroid conditions. Motif analysis of identified TR peaks suggests that the presence and strength of the TRE (DR-4) and chromatin accessibility are important determinants of $\mathrm{TR}$ recruitment in the absence of $T_{3}$, where unliganded TR preferentially binds to accessible chromatin regions containing strong consensus TREs. When $\mathrm{T}_{3}$ is available, $\mathrm{TR}$ is able to occupy accessible chromatin harboring less stringent TR-binding motifs. Only strong, highly conserved TR-binding motifs and presence of $\mathrm{T}_{3}$ allow for TR binding at sites within inaccessible chromatin, which are remodeled de novo upon $\mathrm{T}_{3}$-dependent $\mathrm{TR}$ recruitment. These findings suggest that the role of co-activators and co-repressors in the TR-mediated transcriptional regulation may depend on the type of response element and overall chromatin context. Indeed, only genes with nearby $\mathrm{T}_{3}$-independent TR-binding peaks can be actively repressed by TR in that state. Examples of such genes include $G p d 2, P d p 2$, and $I d h 3$, where at least one of the identified TR-binding sites was found to be hormone-independent. In agreement with the previous studies showing that Gpd2 and $I d h 3 a$ are significantly derepressed in hypothyroid $L-N C o R \Delta I D$ animals that lack interaction between TR and NCoR, activation of these genes is not associated with considerable change of TR occupancy or chromatin remodeling, while NCoR and HDAC3 occupancy is reduced in response to $\mathrm{T}_{3}$. At the same time, co-activator CBP was found at those TR-binding sites at all times. Dio1 represents a class of genes, where all nearby TR binding is ligand-dependent and TR recruitment leads to dramatic remodeling of the chromatin surrounding binding sites. The presence of $\mathrm{T}_{3}$ leads to increased recruitment of co-activator CBP, whereas NCoR and HDAC3 occupancy remains unchanged, suggesting that Dio1 is not directly repressed by TR in the absence of TH. This is again in agreement with the fact that disruption of NCoR-HDAC3 and NCoRTR interactions have been reported to have little effect on Dio1 transcription in the liver.

Published by Bioscientifica Ltd. 
A few general conclusions can be drawn from these data. All of the studies point to DR- 4 as a consensus TR-binding element. Three out of four reports found no significant enrichment in the TR recruitment to the genes negatively regulated by TRs, at least within the proximity limits set in the studies $(10-50 \mathrm{~kb}$ from TSS), suggesting that negative regulation by TH may be largely mediated by indirect mechanisms or TR recruitment in these cases occurs almost exclusively at distant enhancers. In the report by Ramadoss et al. (2013), where TR binding was found to be associated with negatively regulated genes, the enrichment was much lower than for positive genes. While this result still suggests that indirect mechanisms may be responsible for the regulation of a large percentage of negative TH targets, this study also identified DR-0 as a potential 'negative' TRE. Finally, the two in vivo studies found that, unexpectedly, TR recruitment to DNA is influenced by $\mathrm{T}_{3}$, and $\mathrm{T}_{3}$-induced TR binding or release affects target gene expression. Most strikingly, while majority of TR-binding sites were found to reside within open chromatin regions, it was also demonstrated that upon ligand binding TR can bind previously inaccessible chromatin regions and induce chromatin remodeling, similar to other NRs (Boergesen et al. 2012). These new insights into different scenarios of TR action imply that the role of co-activators and co-repressors in TR signaling may vary significantly depending on the type of TR-binding site and surrounding chromatin landscape (Fig. 2).

\section{Summary and future perspectives}

Mouse models with disrupted co-regulator function overall demonstrate that co-activators and co-repressors play a role in the regulation of transcription by TRs not only in the presence or absence of TH respectively, but are also essential for the normal signaling by TR

\section{A T3-independent recruitment of TR}

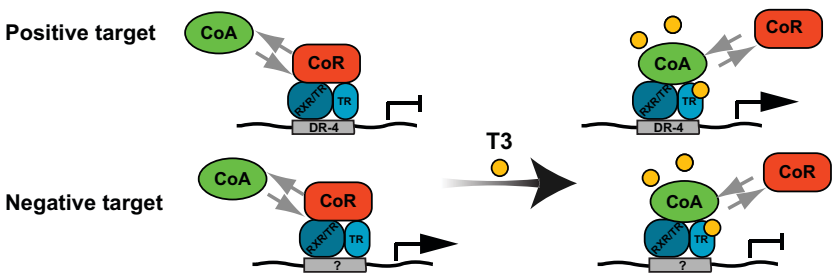

B T3-modulated recruitment of TR

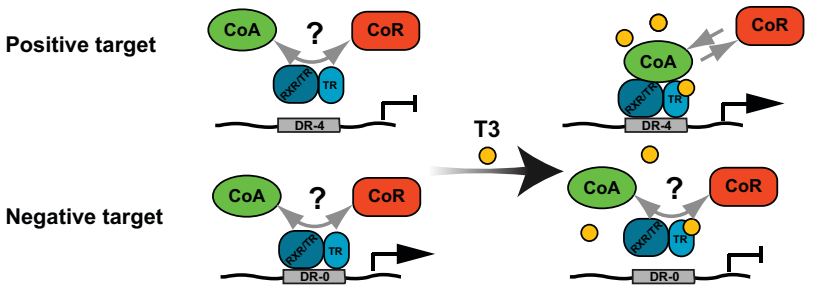

\section{Postivie regulation through T3-induced recruitment of TR}

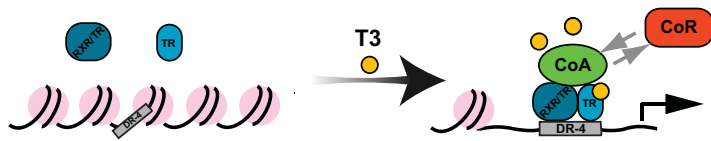

\section{Negative regulation through inderect recruitment of TR}

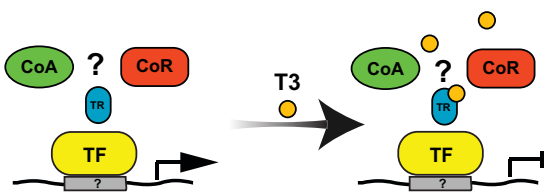

Figure 2

Models of TR-mediated regulation of transcription based on the insights obtained from TR ChIP-seq experiments. Possible roles of co-regulators are hypothesized based on in vitro binding data, animal models with altered co-regulator function, and a limited number of ChIP-PCR experiments. (A) Positively and negatively regulated genes, where TR is recruited to an open chromatin region independently of $\mathrm{T}_{3}$ (based on classic bimodal switch model). On a positively regulated target gene, with a consensus DR-4 TR-binding site, in the absence of TH RXR/TR heterodimer or TR/TR homodimer preferentially recruits co-repressor complex to repress transcription. Upon binding of $\mathrm{T}_{3}$, a conformational change occurs that favors recruitment of co-activators to activate transcription. On negatively regulated targets, with yet undetermined consensus binding site, co-repressor complexes are recruited in the absence of hormone to activate transcription, while co-activators recruited to the liganded TR, mediate transcriptional repression. (B) Positively and negatively regulated genes, where TR binding to open chromatin is affected by $T_{3}$. On a positive target gene containing a DR-4binding site, there is weak TR recruitment in the absence of hormone. In the presence of $T_{3}$, TR strongly binds to the response element and brings co-activator complexes to activate transcription. On a negatively regulated gene, TR is recruited to DR-0 response element in the absence of hormone to activate transcription either through ligand-independent recruitment of co-activators or by recruitment of co-repressors, which act as functional co-activators. Binding of $\mathrm{T}_{3}$ leads to dissociation of TR from DNA and diminished transcription of the target gene. (C) A positively regulated gene located within a region of inaccessible chromatin and containing a strong DR-4 TR-binding motif. TR can only be recruited in the presence of $T_{3}$ to initiate chromatin remodeling and bring co-activator complex to activate transcription. (D) Negative TH-dependent regulation mediated by indirect recruitment of TR and co-regulators through yet unidentified transcription factors (TF).

http://jme.endocrinology-journals.org DOI: 10.1530/JME-15-0246 (c) 2016 Society for Endocrinology Printed in Great Britain
Published by Bioscientifica Ltd 
isoforms under a range of TH concentrations. Removal of co-repressor or co-activator function produces a shift in the dynamics of cofactor recruitment and balance of transcriptional activation vs repression that underlies TR actions. Lack of co-repressor recruitment results in a higher percentage of the receptors that are available to bind $\mathrm{T}_{3}$ and co-activators, thus increasing TR sensitivity and transcriptional response to the hormone. At the same time, co-activator removal not only precludes binding of other components of co-activator complex necessary for maximal transcriptional activation, but also leads to enhanced recruitment of co-repressors, thus 'locking' TRs in the repressive mode.

Studies using animal models have also confirmed that co-regulator specificity does exist in vivo, with NCoR and SRC1 being the preferred co-repressor and co-activator for TR isoforms. SMRT and SRC2 appear to be a 'second-tier' co-regulator and can only minimally, if at all, compensate for the absence of NCoR and SRC1 in the context of TH signaling. In fact, the role of SMRT and SRC2 only becomes apparent in the compound knockout models, such as $\operatorname{Src1}^{-1-/ S r c 2^{-/-}}$(Weiss et al. 2002), L-NCoRAID/Smrt--- (Shimizu et al. 2015), and NCoRAID/Src1-/- (Vella et al. 2014).

At the same time, the role of co-regulators in the control of expression of negative TH targets remains unclear. It has been proposed that co-activators and co-repressors paradoxically play the opposite roles on negative targets. The only definitive in vivo proof of co-repressors playing a role in direct transcriptional activation in the absence of $\mathrm{TH}$ is activation of expression of Klf2 in the lung during neonatal period (Pei et al. 2011). Most studies so far found little to no role for co-regulators in the negative regulation by $\mathrm{TH}$ in peripheral tissues. While many models with disrupted co-activator or co-repressor function demonstrate abnormal regulation of HPT axis to some degree, whether these effects are mediated through direct regulation by TRs remains unclear.

This is further substantiated by genome-wide TR recruitment data, where three out of four studies have found no evidence for direct TR binding near the genes negatively regulated by $\mathrm{T}_{3}$ (Ayers et al. 2014, Chatonnet et al. 2013, Grontved et al. 2015), and one suggested an entirely new mechanism, where negative regulation is achieved through diminished recruitment of TRs in the presence of $T_{3}$ (Ramadoss et al. 2013). These results suggest that negative $\mathrm{TH}$ targets may still be regulated directly by TR, but TR binding in this case occurs preferentially at very distal enhancer sites and therefore cannot be assigned to the negatively regulated genes by proximity in ChIP-seq experiments. Alternatively, TH-dependent negative regulation may be indirect, which includes recruitment of TR to DNA through tethering to other transcription factors or regulation by products of genes directly regulated by TRs.

Mouse models have definitively demonstrated that alterations in co-regulator recruitment can lead to resistance or increased sensitivity to $\mathrm{TH}$, and may also modulate phenotypic presentation of RTH caused by mutations in either TR isoform. However, human patients with disturbances in $\mathrm{TH}$ signaling due to abnormal co-regulator recruitment, function, and/or expression remain to be identified. Importantly, clinical features of these groups of patients are likely to vary widely and display more phenotypic presentations than the two types of TR-dependent RTH.

Genome-wide interrogation of TR binding also demonstrated that there is a wide repertoire of the TR-binding sites that control expression of $\mathrm{TH}$ target genes, and the mode of TR and co-regulator recruitment and function at these sites may vary considerably. Therefore, it is not surprising that in vivo functions of co-activators and co-repressors may appear different depending on the target gene. ChIP-seq data on genomic occupancy of some co-regulators are currently available (Feng et al. 2011, Stashi et al. 2014a, TannourLouet et al. 2014). However, it would be useful to re-evaluate genomic recruitment of co-regulators as well as distribution of histone modifications indicative of transcriptional activation/repression under different thyroid conditions (hypo-, eu-, and hyperthyroid) and align it with TR-binding sites. Such analysis will help put the genome-wide co-regulator binding data in the context of TR signaling, particularly now, when it became evident that thyroid status may greatly influence genomic TR binding. Moreover, while ChAP-seq and ChIP-seq data regarding chromatin TR binding provided great insight into the mechanisms of transcriptional regulation by TRs, these methods suffer certain limitations. Combining existing TR-binding data with Hi-C performed under different TH conditions, or new ChIA-PET experiments for genomic TR-binding will help to better inform us about TR-regulated distant enhancers, and potentially shed light on the negative regulation by TRs. Furthermore, comparison of TR cistrome with those of other NR prominent in the specific cell-type (e.g. LXR, PPAR, Rev-ErbA in the liver) could help better understand the interplay between the different pathways, and how their roles change under different physiological conditions.

Published by Bioscientifica Ltd. 


\section{Declaration of interest}

The author declares that there is no conflict of interest that could be perceived as prejudicing the impartiality of this review.

\section{Funding}

This work was supported by ATA Research Grant (2011).

\section{Acknowledgements}

The author is grateful to $\mathrm{Dr}$ Anthony $\mathrm{N}$ Hollenebrg for discussions and critical reading of the manuscript.

\section{References}

Abel ED, Ahima RS, Boers ME, Elmquist JK \& Wondisford FE 2001 Critical role for thyroid hormone receptor beta2 in the regulation of paraventricular thyrotropin-releasing hormone neurons. Journal of Clinical Investigation 107 1017-1023. (doi:10.1172/JCI10858)

Abel ED, Kaulbach HC, Campos-Barros A, Ahima RS, Boers ME, Hashimoto K, Forrest D \& Wondisford FE 1999 Novel insight from transgenic mice into thyroid hormone resistance and the regulation of thyrotropin. Journal of Clinical Investigation 103 271-279. (doi:10.1172/JCI5205)

Adams M, Matthews C, Collingwood TN, Tone Y, Beck-Peccoz P \& Chatterjee KK 1994 Genetic analysis of 29 kindreds with generalized and pituitary resistance to thyroid hormone. Identification of thirteen novel mutations in the thyroid hormone receptor beta gene. Journal of Clinical Investigation 94 506-515. (doi:10.1172/ JCI117362)

Alenghat T, Meyers K, Mullican SE, Leitner K, Adeniji-Adele A, Avila J, Bucan M, Ahima RS, Kaestner KH \& Lazar MA 2008 Nuclear receptor corepressor and histone deacetylase 3 govern circadian metabolic physiology. Nature 456 997-1000. (doi:10.1038/nature07541)

Alland L, Muhle R, Hou HJ, Potes J, Chin L, Schreiber-Agus N \& DePinho RA 1997 Role for NCoR and histone deacetylase in Sin3-mediated transcriptional repression. Nature 387 49-55. (doi:10.1038/387049a0)

Alonso M, Goodwin C, Liao X, Ortiga-Carvalho T, Machado DS, Wondisford FE, Refetoff S \& Weiss RE 2009 In vivo interaction of steroid receptor coactivator (SRC)-1 and the activation function-2 domain of the thyroid hormone receptor (TR) beta in TRbeta E457A knock-in and Src1 knockout mice. Endocrinology 150 3927-3934. (doi:10.1210/en.2009-0093)

Arrojo EDR, Fonseca TL, Werneck-de-Castro JP \& Bianco AC 2013 Role of the type 2 iodothyronine deiodinase (D2) in the control of thyroid hormone signaling. Biochimica et Biophysica Acta 1830 3956-3964. (doi:10.1016/j.bbagen.2012.08.019)

Astapova I, Lee LJ, Morales C, Tauber S, Bilban M \& Hollenberg AN 2008 The nuclear corepressor, NCoR, regulates thyroid hormone action in vivo. PNAS 105 19544-19549. (doi:10.1073/pnas.0804604105)

Astapova I, Vella KR, Ramadoss P, Holtz KA, Rodwin BA, Liao XH, Weiss RE, Rosenberg MA, Rosenzweig A \& Hollenberg AN 2011 The nuclear receptor corepressor (NCoR) controls thyroid hormone sensitivity and the set point of the hypothalamic-pituitary-thyroid axis. Molecular Endocrinology 25 212-224. (doi:10.1210/me.2010-0462)

Ayers S, Switnicki MP, Angajala A, Lammel J, Arumanayagam AS \& Webb P 2014 Genome-wide binding patterns of thyroid hormone receptor beta. PLoS One 9 e81186. (doi:10.1371/journal. pone.0081186)

Baniahmad A, Leng X, Burris TP, Tsai SY, Tsai MJ \& O'Malley BW 1995 The tau 4 activation domain of the thyroid hormone receptor is required for release of a putative corepressor(s) necessary for transcriptional silencing. Molecular and Cellular Biology 15 76-86. (doi:10.1128/MCB.15.1.76)

Baumann CT, Maruvada P, Hager GL \& Yen PM 2001 Nuclear cytoplasmic shuttling by thyroid hormone receptors. multiple protein interactions are required for nuclear retention. Journal of Biological Chemistry 276 11237-11245. (doi:10.1074/jbc. M011112200)

Beck-Peccoz P \& Chatterjee VK 1994 The variable clinical phenotype in thyroid hormone resistance syndrome. Thyroid 4 225-232. (doi:10.1089/thy.1994.4.225)

Bernal J, Guadano-Ferraz A \& Morte B 2015 Thyroid hormone transporters-functions and clinical implications. Nature Reviews Endocrinology 11 406-417. (doi:10.1038/nrendo.2015.66)

Bhaskara S, Chyla BJ, Amann JM, Knutson SK, Cortez D, Sun ZW \& Hiebert SW 2008 Deletion of histone deacetylase 3 reveals critical roles in S phase progression and DNA damage control. Molecular Cell 30 61-72. (doi:10.1016/j.molcel.2008.02.030)

Bochukova E, Schoenmakers N, Agostini M, Schoenmakers E, Rajanayagam O, Keogh JM, Henning E, Reinemund J, Gevers E, Sarri M, et al. 2012 A mutation in the thyroid hormone receptor alpha gene. New England Journal of Medicine 366 243-249. (doi:10.1056/NEJMoa1110296)

Boergesen M, Pedersen TA, Gross B, van Heeringen SJ, Hagenbeek D, Bindesboll C, Caron S, Lalloyer F, Steffensen KR, Nebb HI, et al. 2012 Genome-wide profiling of liver $\mathrm{X}$ receptor, retinoid $\mathrm{X}$ receptor, and peroxisome proliferator-activated receptor alpha in mouse liver reveals extensive sharing of binding sites. Molecular and Cellular Biology 32 852-867. (doi:10.1128/MCB.06175-11)

Brent GA 2012 Mechanisms of thyroid hormone action. Journal of Clinical Investigation 122 3035-3043. (doi:10.1172/JCI60047)

Brent GA, Dunn MK, Harney JW, Gulick T, Larsen PR \& Moore DD 1989 Thyroid hormone aporeceptor represses T3-inducible promoters and blocks activity of the retinoic acid receptor. New Biology $1329-336$.

Cavailles V, Dauvois S, Danielian PS \& Parker MG 1994 Interaction of proteins with transcriptionally active estrogen receptors. PNAS 91 10009-10013. (doi:10.1073/pnas.91.21.10009)

Charalambous M \& Hernandez A 2013 Genomic imprinting of the type 3 thyroid hormone deiodinase gene: Regulation and developmental implications. Biochimica et Biophysics Acta 1830 3946-3955. (doi:10.1016/j.bbagen.2012.03.015)

Chatonnet F, Guyot R, Benoit G \& Flamant F 2013 Genome-wide analysis of thyroid hormone receptors shared and specific functions in neural cells. PNAS 110 E766-E775. (doi:10.1073/pnas.1210626110)

Chatterjee VK, Lee JK, Rentoumis A \& Jameson JL 1989 Negative regulation of the thyroid-stimulating hormone alpha gene by thyroid hormone: Receptor interaction adjacent to the TATA box. PNAS 86 9114-9118. (doi:10.1073/pnas.86.23.9114)

Chen D, Ma H, Hong H, Koh SS, Huang SM, Schurter BT, Aswad DW \& Stallcup MR 1999 Regulation of transcription by a protein methyltransferase. Science 284 2174-2177. (doi:10.1126/ science.284.5423.2174)

Chen H, Lin RJ, Schlitz RL, Chakravarti D, Nash A, Nagy L, Privalsky M, Nakatani Y \& Evans RM 1997 Nuclear receptor coactivator ACTR is a novel histone acetyltransferase and forms a multimeric activation complex with P/CAF and CBP/p300. Cell 90 569-580. (doi:10.1016/ S0092-8674(00)80516-4)

Chen JD \& Evans RM 1995 A transcriptional co-repressor that interacts with nuclear hormone receptors. Nature 377 454-457. (doi:10.1038/377454a0)

Cheng SY, Leonard JL \& Davis PJ 2010 Molecular aspects of thyroid hormone actions. Endocrine Reviews 31 139-170. (doi:10.1210/ er.2009-0007)

Chiamolera MI \& Wondisford FE 2009 Minireview: Thyrotropinreleasing hormone and the thyroid hormone feedback mechanism. Endocrinology 150 1091-1096. (doi:10.1210/en.2008-1795) 
Chopra AR, Kommagani R, Saha P, Louet JF, Salazar C, Song J, Jeong J, Finegold M, Viollet B, DeMayo F et al. 2011 Cellular energy depletion resets whole-body energy by promoting coactivatormediated dietary fuel absorption. Cell Metabolism 13 35-43. (doi:10.1016/j.cmet.2010.12.001)

Chopra AR, Louet JF, Saha P, An J, Demayo F, Xu J, York B, Karpen S, Finegold M, Moore D et al. 2008 Absence of the Src2 coactivator results in a glycogenopathy resembling Von Gierke's disease. Science 322 1395-1399. (doi:10.1126/science.1164847)

Christoffolete MA, Doleschall M, Egri P, Liposits Z, Zavacki AM, Bianco AC \& Gereben B 2010 Regulation of thyroid hormone activation via the liver X-receptor/retinoid X-receptor pathway. Journal of Endocrinology 205 179-186. (doi:10.1677/JOE-09-0448)

Cohen RN, Brzostek S, Kim B, Chorev M, Wondisford FE \& Hollenberg AN 2001 The specificity of interactions between nuclear hormone receptors and corepressors is mediated by distinct amino acid sequences within the interacting domains. Molecular Endocrinology 15 1049-1061. (doi:10.1210/mend.15.7.0669)

Cohen RN, Putney A, Wondisford FE \& Hollenberg AN 2000 The nuclear corepressors recognize distinct nuclear receptor complexes. Molecular Endocrinology 14 900-914. (doi:10.1210/mend.14.6.0474)

Collingwood TN, Rajanayagam O, Adams M, Wagner R, Cavailles V, Kalkhoven E, Matthews C, Nystrom E, Stenlof K, Lindstedt G et al. 1997 A natural transactivation mutation in the thyroid hormone beta receptor: Impaired interaction with putative transcriptional mediators. PNAS 94 248-253.

Collingwood TN, Wagner R, Matthews $\mathrm{CH}$, Clifton-Bligh RJ, Gurnell M, Rajanayagam O, Agostini M, Fletterick RJ, Beck-Peccoz P, Reinhardt W, et al. 1998 A role for helix 3 of the TRbeta ligand-binding domain in coactivator recruitment identified by characterization of a third cluster of mutations in resistance to thyroid hormone. EMBO Journal 17 4760-4770. (doi:10.1093/emboj/17.16.4760)

Costa-e-Sousa RH, Astapova I, Ye F, Wondisford FE \& Hollenberg AN 2012 The thyroid axis is regulated by NCoR1 via its actions in the pituitary. Endocrinology 153 5049-5057. (doi:10.1210/ en.2012-1504)

Coste A, Louet JF, Lagouge M, Lerin C, Antal MC, Meziane H, Schoonjans K, Puigserver P, O’Malley BW \& Auwerx J 2008 The genetic ablation of $S r c 3$ protects against obesity and improves insulin sensitivity by reducing the acetylation of PGC-1\{alpha\}. PNAS $\mathbf{1 0 5}$ 17187-17192. (doi:10.1073/pnas.0808207105)

Damm K, Thompson CC \& Evans RM 1989 Protein encoded by v-erbA functions as a thyroid-hormone receptor antagonist. Nature 339 593-597. (doi:10.1038/339593a0)

Darimont BD, Wagner RL, Apriletti JW, Stallcup MR, Kushner PJ, Baxter JD, Fletterick RJ \& Yamamoto KR 1998 Structure and specificity of nuclear receptor-coactivator interactions. Genes \& Development 12 3343-3356. (doi:10.1101/gad.12.21.3343)

Darling DS, Burnside J \& Chin WW 1989 Binding of thyroid hormone receptors to the rat thyrotropin-beta gene. Molecular Endocrinology 3 1359-1368. (doi:10.1210/mend-3-9-1359)

Dasgupta S, Lonard DM \& O'Malley BW 2014 Nuclear receptor coactivators: Master regulators of human health and disease. Annual Review of Medicine 65 279-292. (doi:10.1146/annurevmed-051812-145316)

Dasgupta S \& O'Malley BW 2014 Transcriptional coregulators: Emerging roles of SRC family of coactivators in disease pathology. Journal of Molecular Endocrinology 53 R47-59. (doi:10.1530/JME-14-0080)

Dumitrescu AM \& Refetoff S 2013 The syndromes of reduced sensitivity to thyroid hormone. Biochimica et Biophysica Acta 1830 3987-4003. (doi:10.1016/j.bbagen.2012.08.005)

Espiard S, Savagner F, Flamant F, Vlaeminck-Guillem V, Guyot R, Munier M, d'Herbomez M, Bourguet W, Pinto G, Rose C, et al. 2015 A novel mutation in THRA gene associated with an atypical phenotype of resistance to thyroid hormone. Journal of the Clinical Endocrinology Metabolism 100 2841-2848. (doi:10.1210/ jc. 2015-1120)
Faist F, Short S, Kneale GG \& Sharpe CR 2009 Alternative splicing determines the interaction of SMRT isoforms with nuclear receptorDNA complexes. Bioscience Reports 29 143-149. (doi:10.1042/ BSR20080093)

Fang S, Suh JM, Atkins AR, Hong SH, Leblanc M, Nofsinger RR, Yu RT, Downes M \& Evans RM 2010 Corepressor SMRT promotes oxidative phosphorylation in adipose tissue and protects against diet-induced obesity and insulin resistance. PNAS 108 3412-3417. (doi:10.1073/ pnas.1017707108)

Feng D, Liu T, Sun Z, Bugge A, Mullican SE, Alenghat T, Liu XS \& Lazar MA 2011 A circadian rhythm orchestrated by histone deacetylase 3 controls hepatic lipid metabolism. Science $\mathbf{3 3 1}$ 1315-1319. (doi:10.1126/science.1198125)

Feng Q, He B, Jung SY, Song Y, Qin J, Tsai SY, Tsai MJ \& O'Malley BW 2009 Biochemical control of CARM1 enzymatic activity by phosphorylation. Journal of Biological Chemistry 284 36167-36174. (doi:10.1074/jbc.M109.065524)

Feng W, Ribeiro RCJ, Wagner RL, Nguyen H, Apriletti JW, Fletterick RJ, Baxter JD, Kushner PJ \& West BL 1998 Hormone-dependent coactivator binding to a hydrophobic cleft on nuclear receptors. Science 280 1747-1749. (doi:10.1126/science.280.5370.1747)

Feng X, Jiang Y, Meltzer P \& Yen PM 2000 Thyroid hormone regulation of hepatic genes in vivo detected by complementary DNA microarray. Molecular Endocrinology 14 947-955. (doi:10.1210/ mend.14.7.0470)

Flamant F, Poguet AL, Plateroti M, Chassande O, Gauthier K, Streichenberger N, Mansouri A \& Samarut J 2002 Congenital hypothyroid Pax8(-/-) mutant mice can be rescued by inactivating the TRalpha gene. Molecular Endocrinology 16 24-32. (doi:10.1210/ mend.16.1.0766)

Flamant F \& Samarut J 2003 Thyroid hormone receptors: Lessons from knockout and knock-in mutant mice. Trends in Endocrinology \& Metabolism 14 85-90. (doi:10.1016/S1043-2760(02)00043-7)

Flores-Morales A, Gullberg H, Fernandez L, Stahlberg N, Lee NH, Vennstrom B \& Norstedt G 2002 Patterns of liver gene expression governed by TRbeta. Molecular Endocrinology 16 1257-1268. (doi:10.1210/mend.16.6.0846)

Fonseca TL, Correa-Medina M, Campos MP, Wittmann G, Werneck-de-Castro JP, Arrojo e Drigo R, Mora-Garzon M, Ueta CB, Caicedo A, Fekete C, et al. 2013 Coordination of hypothalamic and pituitary T3 production regulates TSH expression. Journal of Clinical Investigation 123 1492-1500. (doi:10.1172/JCI61231)

Fozzatti L, Kim DW, Park JW, Willingham MC, Hollenberg AN \& Cheng SY 2013 Nuclear receptor corepressor (NCOR1) regulates in vivo actions of a mutated thyroid hormone receptor alpha. PNAS 110 7850-7855. (doi:10.1073/ pnas.1222334110)

Fozzatti L, Lu C, Kim DW, Park JW, Astapova I, Gavrilova O, Willingham MC, Hollenberg AN \& Cheng SY 2011 Resistance to thyroid hormone is modulated in vivo by the nuclear receptor corepressor (NCOR1). PNAS 108 17462-17467. (doi:10.1073/ pnas.1107474108)

Gehin M, Mark M, Dennefeld C, Dierich A, Gronemeyer H \& Chambon P 2002 The function of TIF2/GRIP1 in mouse reproduction is distinct from those of Src1 and p/CIP. Molecular and Cellular Biology 22 5923-5937. (doi:10.1128/MCB.22.16.59235937.2002)

Gereben B, Zavacki AM, Ribich S, Kim BW, Huang SA, Simonides WS, Zeold A \& Bianco AC 2008 Cellular and molecular basis of deiodinase-regulated thyroid hormone signaling. Endocrine Reviews 29 898-938. (doi:10.1210/er.2008-0019)

Glass CK, Franco R, Weinberger C, Albert VR, Evans RM \& Rosenfeld MG 1987 A c-erb-A binding site in rat growth hormone gene mediates trans-activation by thyroid hormone. Nature $\mathbf{3 2 9}$ 738-741. (doi:10.1038/329738a0)

Glass CK, Holloway JM, Devary OV \& Rosenfeld MG 1988 The thyroid hormone receptor binds with opposite transcriptional effects to a

Published by Bioscientifica Ltd 
common sequence motif in thyroid hormone and estrogen response elements. Cell 54 313-323. (doi:10.1016/00928674(88)90194-8)

Glass CK \& Rosenfeld MG 2000 The coregulator exchange in transcriptional functions of nuclear receptors. Genes \& Development 14 121-141. (doi:10.1101/gad.14.2.121)

Goodson ML, Mengeling BJ, Jonas BA \& Privalsky ML 2011 Alternative mRNA splicing of corepressors generates variants that play opposing roles in adipocyte differentiation. Journal of Biological Chemistry 286 44988-44999. (doi:10.1074/jbc.M111.291625)

Goodson ML, Young BM, Snyder CA, Schroeder AC \& Privalsky ML 2014 Alteration of NCoR corepressor splicing in mice causes increased body weight and hepatosteatosis without glucose intolerance. Molecular and Cellular Biology 34 4104-4114. (doi:10.1128/ MCB.00554-14)

Grontved L, Waterfall JJ, Kim DW, Baek S, Sung MH, Zhao L, Park JW, Nielsen R, Walker RL, Zhu YJ et al. 2015 Transcriptional activation by the thyroid hormone receptor through ligand-dependent receptor recruitment and chromatin remodelling. Nature Communications 6 7048. (doi:10.1038/ncomms8048)

Guenther MG, Barak O \& Lazar MA 2001 The SMRT and NCoR corepressors are activating cofactors for histone deacetylase 3 . Molecular and Cellular Biology 21 6091-6101. (doi:10.1128/ MCB.21.18.6091-6101.2001)

Guenther MG, Lane WS, Fischle W, Verdin E, Lazar MA \& Shiekhattar R 2000 A core SMRT corepressor complex containing HDAC3 and TBL1, a WD40-repeat protein linked to deafness. Genes \& Development 14 1048-1057. (doi:10.1101/gad.14.9.1048)

Halachmi S, Marden E, Martin G, Mackay H, Abbondanza C \& Brown M 1994 Estrogen receptor-associated proteins-possible mediators of hormone-induced transcription. Science 264 1455-1458. (doi:10.1126/science.8197458)

Hashimoto K, Curty FH, Borges PP, Lee CE, Abel ED, Elmquist JK, Cohen RN \& Wondisford FE 2001 An unliganded thyroid hormone receptor causes severe neurological dysfunction. PNAS 98 3998-4003. (doi:10.1073/pnas.051454698)

Hashimoto K \& Mori M 2011 Crosstalk of thyroid hormone receptor and liver X receptor in lipid metabolism and beyond. Endocrinology Journal 58 921-930. (doi:10.1507/endocrj.EJ11-0114)

Hayashi Y, Weiss RE, Sarne DH, Yen PM, Sunthornthepvarakul T, Marcocci C, Chin WW \& Refetoff S 1995 Do clinical manifestations of resistance to thyroid hormone correlate with the functional alteration of the corresponding mutant thyroid hormone-beta receptors? Journal of Clinical Endocrinology and Metabolism 80 3246-3256. (doi:10.1210/jcem.80.11.7593433)

Heery DM, Kalkhoven E, Hoare S \& Parker MG 1997 A signature motif in transcriptional co-activators mediates binding to nuclear receptors. Nature 387 733-736. (doi:10.1038/42750)

Heinzel T, Lavinsky RM, Mullen TM, Soderstrom M, Laherty CD, Torchia J, Yang WM, Brard G, Ngo SD, Davie JR, et al. 1997 A complex containing NCoR, mSin3 and histone deacetylase mediates transcriptional repression. Nature 387 43-48. (doi:10.1038/387043a0)

Hernandez A, Martinez ME, Liao XH, Van Sande J, Refetoff S, Galton VA \& St Germain DL 2007 Type 3 deiodinase deficiency results in functional abnormalities at multiple levels of the thyroid axis. Endocrinology 148 5680-5687. (doi:10.1210/en.2007-0652)

Heuer H \& Visser TJ 2013 The pathophysiological consequences of thyroid hormone transporter deficiencies: Insights from mouse models. Biochimica et Biophysica Acta 1830 3974-3978. (doi:10.1016/j.bbagen.2012.04.009)

Hodin RA, Lazar MA, Wintman BI, Darling DS, Koenig RJ, Larsen PR, Moore DD \& Chin WW 1989 Identification of a thyroid hormone receptor that is pituitary-specific. Science 244 76-79. (doi:10.1126/ science.2539642)

Hoftijzer HC, Heemstra KA, Visser TJ, le Cessie S, Peeters RP, Corssmit EP \& Smit JW 2011 The type 2 deiodinase ORFa-Gly3Asp polymorphism (rs12885300) influences the set point of the hypothalamus-pituitarythyroid axis in patients treated for differentiated thyroid carcinoma. Journal of Clinical Endocrinology and Metabolism 96 E1527-1533. (doi:10.1210/jc.2011-0235)

Hollenberg AN, Monden T, Flynn TR, Boers M-E, Cohen O \& Wondisford FE 1995 The human thyrotropin-releasing hormone gene is regulated by thyroid hormone through two distinct classes of negative thyroid hormone response elements. Molecular Endocrinology 10 540-550. (doi:10.1210/mend.9.5.7565802)

Horlein AJ, Naar AM, Heinzel T, Torchia J, Gloss B, Kurokawa R, Ryan A, Kamei Y, Soderstrom M, Glass CK, et al. 1995 Ligand-independent repression by the thyroid hormone receptor mediated by a nuclear receptor co-repressor. Nature 377 397-404. (doi:10.1038/377397a0)

Hu X \& Lazar MA 1999 The CoRNR motif controls the recruitment of corepressors by nuclear hormone receptors. Nature 402 93-96. (doi:10.1038/47069)

Ishizuka T \& Lazar MA 2003 The NCoR/histone deacetylase 3 complex is required for repression by thyroid hormone receptor. Molecular and Cellular Biology 23 5122-5131. (doi:10.1128/MCB.23.15.5122-5131.2003)

Ishizuka T \& Lazar MA 2005 The nuclear receptor corepressor deacetylase activating domain is essential for repression by thyroid hormone receptor. Molecular Endocrinology19 1443-1451. (doi:10.1210/me.2005-0009)

Ito M \& Roeder RG 2001 The TRAP/SMCC/Mediator complex and thyroid hormone receptor function. Trends in Endocrinology \& Metabolism 12 127-134. (doi:10.1016/S1043-2760(00)00355-6)

Iwasaki T, Takeshita A, Miyazaki W, Chin WW \& Koibuchi N 2006 The interaction of TRbeta1-N terminus with steroid receptor coactivator-1 (Src1) serves a full transcriptional activation function of Src1. Endocrinology 147 1452-1457. (doi:10.1210/en.2005-0782)

Jackson-Hayes L, Song S, Lavrentyev EN, Jansen MS, Hillgartner FB, Tian L, Wood PA, Cook GA \& Park EA 2003 A thyroid hormone response unit formed between the promoter and first intron of the carnitine palmitoyltransferase-Ialpha gene mediates the liver-specific induction by thyroid hormone. Journal of Biological Chemistry $\mathbf{2 7 8}$ 7964-7972. (doi:10.1074/jbc.M211062200)

Jepsen K, Gleiberman AS, Shi C, Simon DI \& Rosenfeld MG 2008 Cooperative regulation in development by SMRT and FOXP1. Genes \& Development 22 740-745. (doi:10.1101/gad.1637108)

Jepsen K, Hermanson O, Onami TM, Gleiberman AS, Lunyak V, McEvilly RJ, Kurokawa R, Kumar V, Liu F, Seto E, et al. 2000 Combinatorial roles of the nuclear receptor corepressor in transcription and development. Cell 102 753-763. (doi:10.1016/ S0092-8674(00)00064-7)

Jepsen K, Solum D, Zhou T, McEvilly RJ, Kim HJ, Glass CK, Hermanson O \& Rosenfeld MG 2007 SMRT-mediated repression of an H3K27 demethylase in progression from neural stem cell to neuron. Nature 450 415-419. (doi:10.1038/nature06270)

Jo YS, Ryu D, Maida A, Wang X, Evans RM, Schoonjans K \& Auwerx J 2015 Phosphorylation of the nuclear receptor corepressor 1 by protein kinase B switches its corepressor targets in the liver in mice. Hepatology 62 1606-1618. (doi:10.1002/hep.27907)

Johnson AB \& O'Malley BW 2012 Steroid receptor coactivators 1, 2, and 3: Critical regulators of nuclear receptor activity and steroid receptor modulator (SRM)-based cancer therapy. Molecular and Cellular Endocrinology 348 430-439. (doi:10.1016/j.mce.2011.04.021)

Kamiya Y, Zhang XY, Ying H, Kato Y, Willingham MC, Xu J, O'Malley BW \& Cheng SY 2003 Modulation by steroid receptor coactivator-1 of target-tissue responsiveness in resistance to thyroid hormone. Endocrinology 144 4144-4153. (doi:10.1210/en.2003-0239)

Kaneshige M, Kaneshige K, Zhu X, Dace A, Garrett L, Carter TA, Kazlauskaite R, Pankratz DG, Wynshaw-Boris A, Refetoff S, et al. 2000 Mice with a targeted mutation in the thyroid hormone beta receptor gene exhibit impaired growth and resistance to thyroid hormone. PNAS 97 13209-13214. (doi:10.1073/pnas.230285997)

Kaneshige M, Suzuki H, Kaneshige K, Cheng J, Wimbrow H, Barlow C, Willingham MC \& Cheng S 2001 A targeted dominant negative

Published by Bioscientifica Ltd 
mutation of the thyroid hormone alpha 1 receptor causes increased mortality, infertility, and dwarfism in mice. PNAS 98 15095-15100. (doi:10.1073/pnas.261565798)

Knutson SK, Chyla BJ, Amann JM, Bhaskara S, Huppert SS \& Hiebert SW 2008 Liver-specific deletion of histone deacetylase 3 disrupts metabolic transcriptional networks. EMBO Journal 27 1017-1028. (doi:10.1038/emboj.2008.51)

Koenig RJ, Warne RL, Brent GA, Harney JW, Larsen PR \& Moore DD 1988 Isolation of a cDNA clone encoding a biologically active thyroid hormone receptor. PNAS 85 5031-5035. (doi:10.1073/ pnas.85.14.5031)

Koh SS, Chen D, Lee YH \& Stallcup MR 2001 Synergistic enhancement of nuclear receptor function by p160 coactivators and two coactivators with protein methyltransferase activities. Journal of Biological Chemistry 276 1089-1098. (doi:10.1074/jbc. M004228200)

Kouzarides T 2007 Chromatin modifications and their function. Cell 128 693-705. (doi:10.1016/j.cell.2007.02.005)

Li C, Wu RC, Amazit L, Tsai SY, Tsai MJ \& O'Malley BW 2007 Specific amino acid residues in the basic helix-loop-helix domain of $\operatorname{Src3}$ are essential for its nuclear localization and proteasome-dependent turnover. Molecular and Cellular Biology 27 1296-1308. (doi:10.1128/ MCB.00336-06)

Li J, O'Malley BW \& Wong J 2000 p300 requires its histone acetyltransferase activity and $\operatorname{Src1}$ interaction domain to facilitate thyroid hormone receptor activation in chromatin. Molecular and Cellular Biology 20 2031-2042. (doi:10.1128/ MCB.20.6.2031-2042.2000)

Li P, Fan W, Xu J, Lu M, Yamamoto H, Auwerx J, Sears DD, Talukdar S, Oh D, Chen A, et al. 2011 Adipocyte NCoR knockout decreases PPARgamma phosphorylation and enhances PPARgamma activity and insulin sensitivity. Cell 147 815-826. (doi:10.1016/ j.cell.2011.09.050)

Liu Y, Takeshita A, Misiti S, Chin WW \& Yen PM 1998 Lack of coactivator interaction can be a mechanism for dominant negative activity by mutant thyroid hormone receptors. Endocrinology 139 4197-4204. (doi:10.1210/endo.139.10.6218)

Liu YY, Schultz JJ \& Brent GA 2003 A thyroid hormone receptor alpha gene mutation $(\mathrm{P} 398 \mathrm{H})$ is associated with visceral adiposity and impaired catecholamine-stimulated lipolysis in mice. Journal of Biological Chemistry 278 38913-38920. (doi:10.1074/jbc. M306120200)

Louet JF, Chopra AR, Sagen JV, An J, York B, Tannour-Louet M, Saha PK, Stevens RD, Wenner BR, Ilkayeva OR et al. 2010 The coactivator Src1 is an essential coordinator of hepatic glucose production. Cell Metabolism 12 606-618. (doi:10.1016/j.cmet.2010.11.009)

Louet JF, Coste A, Amazit L, Tannour-Louet M, Wu RC, Tsai SY, Tsai MJ, Auwerx J \& O'Malley BW 2006 Oncogenic steroid receptor coactivator-3 is a key regulator of the white adipogenic program. PNAS 103 17868-17873. (doi:10.1073/ pnas.0608711103)

Maglich JM, Watson J, McMillen PJ, Goodwin B, Willson TM \& Moore JT 2004 The nuclear receptor CAR is a regulator of thyroid hormone metabolism during caloric restriction. Journal of Biological Chemistry 279 19832-19838. (doi:10.1074/jbc. M313601200)

Makowski A, Brzostek S, Cohen RN \& Hollenberg AN 2003 Determination of nuclear receptor corepressor interactions with the thyroid hormone receptor. Molecular Endocrinology 17 273-286. (doi:10.1210/me.2002-0310)

Malartre M, Short S \& Sharpe C 2004 Alternative splicing generates multiple SMRT transcripts encoding conserved repressor domains linked to variable transcription factor interaction domains. Nucleic Acids Research 32 4676-4686. (doi:10.1093/nar/gkh786)

McInerney EM, Rose DW, Flynn SE, Westin S, Mullen TM, Krones A, Inostroza J, Torchia J, Nolte RT, Assa-Munt N, et al. 1998
Determinants of coactivator LXXLL motif specificity in nuclear receptor transcriptional activation. Genes \& Development 12 3357-3368. (doi:10.1101/gad.12.21.3357)

McKenna NJ \& O'Malley BW 2002 Combinatorial control of gene expression by nuclear receptors and coregulators. Cell 108 465-474 (doi:10.1016/S0092-8674(02)00641-4)

Miao Y, Wu W, Dai Y, Maneix L, Huang B, Warner M \& Gustafsson JA 2015 Liver X receptor beta controls thyroid hormone feedback in the brain and regulates browning of subcutaneous white adipose tissue. PNAS 112 14006-14011. (doi:10.1073/pnas.1519358112)

Millard CJ, Watson PJ, Fairall L \& Schwabe JW 2013 An evolving understanding of nuclear receptor coregulator proteins. Journal of Molecular Endocrinology 51 T23-T36. (doi:10.1530/ JME-13-0227)

Moore JM, Galicia SJ, McReynolds AC, Nguyen NH, Scanlan TS \& Guy RK 2004 Quantitative proteomics of the thyroid hormone receptor-coregulator interactions. Journal of Biological Chemistry 279 27584-27590. (doi:10.1074/jbc.M403453200)

Moore JM \& Guy RK 2005 Coregulator interactions with the thyroid hormone receptor. Molecular Cell Proteomics 4 475-482. (doi:10.1074/ mcp.R500001-MCP200)

Moran C, Agostini M, Visser WE, Schoenmakers E, Schoenmakers N, Offiah AC, Poole K, Rajanayagam O, Lyons G, Halsall D, et al. 2014 Resistance to thyroid hormone caused by a mutation in thyroid hormone receptor (TR)alpha1 and TRalpha2: Clinical, biochemical, and genetic analyses of three related patients. Lancet Diabetes \& Endocrinology 2 619-626. (doi:10.1016/ S2213-8587(14)70111-1)

Moran C, Schoenmakers N, Agostini M, Schoenmakers E, Offiah A, Kydd A, Kahaly G, Mohr-Kahaly S, Rajanayagam O, Lyons G, et al. 2013 An adult female with resistance to thyroid hormone mediated by defective thyroid hormone receptor alpha. Journal of Clinical Endocrinology and Metabolism 98 4254-4261. (doi:10.1210/ jc.2013-2215)

Mottis A, Mouchiroud L \& Auwerx J 2013 Emerging roles of the corepressors NCoR1 and SMRT in homeostasis. Genes \& Development 27 819-835. (doi:10.1101/gad.214023.113)

Nagy L, Kao HY, Chakravarti D, Lin RJ, Hassig CA, Ayer DE, Schreiber SL \& Evans RM 1997 Nuclear receptor repression mediated by a complex containing SMRT, mSin3A, and histone deacetylase. Cell 89 373-380. (doi:10.1016/S0092-8674(00)80218-4)

Nagy L, Kao HY, Love JD, Li C, Banayo E, Gooch JT, Krishna V, Chatterjee K, Evans RM \& Schwabe JW 1999 Mechanism of corepressor binding and release from nuclear hormone receptors. Genes \& Development 13 3209-3216. (doi:10.1101/ gad.13.24.3209)

Nofsinger RR, Li P, Hong SH, Jonker JW, Barish GD, Ying H, Cheng SY, Leblanc M, Xu W, Pei L, et al. 2008 SMRT repression of nuclear receptors controls the adipogenic set point and metabolic homeostasis. PNAS 105 20021-20026. (doi:10.1073/ pnas.0811012105)

Nolte RT, Wisely GB, Westin S, Cobb JE, Lambert MH, Kurokawa R, Rosenfeld MG, Willson TM, Glass CK \& Milburn MV 1998 Ligand binding and co-activator assembly of the peroxisome proliferator-activated receptor-gamma. Nature 395 137-143. (doi:10.1038/25931)

Oberoi J, Fairall L, Watson PJ, Yang JC, Czimmerer Z, Kampmann T, Goult BT, Greenwood JA, Gooch JT, Kallenberger BC, et al. 2011 Structural basis for the assembly of the SMRT/NCoR core transcriptional repression machinery. Nature Structural \& Molecular Biology 18 177-184. (doi:10.1038/nsmb.1983)

Obregon MJ 2014 Adipose tissues and thyroid hormones. Frontiers in Physiology 5 479. (doi:10.3389/fphys.2014.00479)

Onate SA, Boonyaratanakornkit V, Spencer TE, Tsai SY, Tsai MJ, Edwards DP \& O'Malley BW 1998 The steroid receptor coactivator-1 contains multiple receptor interacting and activation domains that

Published by Bioscientifica Ltd. 
cooperatively enhance the activation function 1 (AF1) and AF2 domains of steroid receptors. Journal of Biological Chemistry 273 12101-12108. (doi:10.1074/jbc.273.20.12101)

Onate SA, Tsai SY, Tsai MJ \& O'Malley BW 1995 Sequence and characterization of a coactivator for the steroid hormone receptor superfamily. Science 270 1354-1357. (doi:10.1126/ science.270.5240.1354)

Oppenheimer JH, Schwartz HL, Lane JT \& Thompson MP 1991 Functional relationship of thyroid hormone-induced lipogenesis, lipolysis, and thermogenesis in the rat. Journal of Clinical Investigation 87 125-132. (doi:10.1172/JCI114961)

Ortiga-Carvalho TM, Shibusawa N, Nikrodhanond A, Oliveira KJ, Machado DS, Liao XH, Cohen RN, Refetoff S \& Wondisford FE 2005 Negative regulation by thyroid hormone receptor requires an intact coactivator-binding surface. Journal of Clinical Investigation $\mathbf{1 1 5}$ 2517-2523. (doi:10.1172/JCI24109)

Pei L, Leblanc M, Barish G, Atkins A, Nofsinger R, Whyte J, Gold D, He M, Kawamura K, Li HR, et al. 2011 Thyroid hormone receptor repression is linked to type I pneumocyte-associated respiratory distress syndrome. Nature Medicince 17 1466-1472. (doi:10.1038/ nm.2450)

Perissi V, Jepsen K, Glass CK \& Rosenfeld MG 2010 Deconstructing repression: Evolving models of co-repressor action. Nature Reviews Genetics 11 109-123. (doi:10.1038/nrg2736)

Perissi V, Staszewski LM, McInerney EM, Kurokawa R, Krones A, Rose DW, Lambert MH, Milburn MV, Glass CK \& Rosenfeld MG 1999 Molecular determinants of nuclear receptor-corepressor interaction. Genes \& Development 13 3198-3208. (doi:10.1101/ gad.13.24.3198)

Perlman AJ, Stanley F \& Samuels HH 1982 Thyroid hormone nuclear receptor. Evidence for multimeric organization in chromatin. Journal of Biological Chemistry 257 930-938.

Petty KJ, Desvergne B, Mitsuhashi T \& Nikodem VM 1990 Identification of a thyroid hormone response element in the malic enzyme gene. Journal of Biological Chemistry 265 7395-7400.

Picard F, Gehin M, Annicotte J, Rocchi S, Champy MF, O'Malley BW, Chambon P \& Auwerx J 2002 Src1 and TIF2 control energy balance between white and brown adipose tissues. Cell 111 931-941. (doi:10.1016/S0092-8674(02)01169-8)

Qatanani M, Zhang J \& Moore DD 2005 Role of the constitutive androstane receptor in xenobiotic-induced thyroid hormone metabolism. Endocrinology 146 995-1002. (doi:10.1210/en.2004-1350)

Quignodon L, Vincent S, Winter H, Samarut J \& Flamant F 2007 A point mutation in the activation function 2 domain of thyroid hormone receptor alpha1 expressed after CRE-mediated recombination partially recapitulates hypothyroidism. Molecular Endocrinology 21 2350-2360. (doi:10.1210/me.2007-0176)

Ramadoss P, Abraham BJ, Tsai L, Zhou Y, Costa ESRH, Ye F, Bilban M, Zhao K \& Hollenberg AN 2013 Novel mechanism of positive versus negative regulation by thyroid hormone receptor beta 1 (TRbeta1) identified by genome-wide profiling of binding sites in mouse liver. Journal of Biological Chemistry 289 1313-1328. (doi:10.1074/jbc. M113.521450)

Refetoff S, DeWind LT \& DeGroot LJ 1967 Familial syndrome combining deaf-mutism, stuppled epiphyses, goiter and abnormally high PBI: Possible target organ refractoriness to thyroid hormone. Journal of Clinical Endocrinology and Metabolism 27 279-294. (doi:10.1210/jcem27-2-279)

Refetoff S, Weiss RE \& Usala SJ 1993 The syndromes of resistance to thyroid hormone. Endocrine Reviews 14 348-399. (doi:10.1210/edrv14-3-348)

Reilly SM, Bhargava P, Liu S, Gangl MR, Gorgun C, Nofsinger RR, Evans RM, Qi L, Hu FB \& Lee CH 2010 Nuclear receptor corepressor SMRT regulates mitochondrial oxidative metabolism and mediates aging-related metabolic deterioration. Cell Metabolism 12 643-653. (doi:10.1016/j.cmet.2010.11.007)
Reutrakul S, Sadow PM, Pannain S, Pohlenz J, Carvalho GA, Macchia PE, Weiss RE \& Refetoff S 2000 Search for abnormalities of nuclear corepressors, coactivators, and a coregulator in families with resistance to thyroid hormone without mutations in thyroid hormone receptor beta or alpha genes. Journal of Clinical Endocrinology and Metabolism 85 3609-3617. (doi:10.1210/ jcem.85.10.6873)

Sadow PM, Chassande O, Gauthier K, Samarut J, Xu J, O'Malley BW \& Weiss RE 2003a Specificity of thyroid hormone receptor subtype and steroid receptor coactivator-1 on thyroid hormone action. American Journal of Physiology. Endocrinology and Metabolism 284 E36-46. (doi:10.1152/ajpendo.00226.2002)

Sadow PM, Koo E, Chassande O, Gauthier K, Samarut J, Xu J, O'Malley BW, Seo H, Murata Y \& Weiss RE 2003b Thyroid hormone receptor-specific interactions with steroid receptor coactivator-1 in the pituitary. Molecular Endocrinology 17 882-894. (doi:10.1210/ me.2002-0174)

Sap J, Munoz A, Damm K, Goldberg Y, Ghysdael J, Leutz A, Beug H \& Vennstrom B 1986 The c-erb-A protein is a high-affinity receptor for thyroid hormone. Nature 324 635-640. (doi:10.1038/324635a0)

Schweizer U \& Kohrle J 2013 Function of thyroid hormone transporters in the central nervous system. Biochimica et Biophysica Acta 1830 3965-3973. (doi:10.1016/j.bbagen.2012.07.015)

Shimizu H, Astapova I, Ye F, Bilban M, Cohen RN \& Hollenberg AN 2015 NCoR1 and SMRT play unique roles in thyroid hormone action in vivo. Molecular and Cellular Biology 35 555-565. (doi:10.1128/ MCB.01208-14)

Sinha RA, You SH, Zhou J, Siddique MM, Bay BH, Zhu X, Privalsky ML, Cheng SY, Stevens RD, Summers SA et al. 2012 Thyroid hormone stimulates hepatic lipid catabolism via activation of autophagy. Journal of Clinical Investigation 122 2428-2438. (doi:10.1172/ JCI60580)

Song Y, Shan S, Zhang Y, Liu W, Ding W, Ren W, Xia H, Li X, Zhang Q Zhao L, et al. 2012 Ligand-dependent corepressor acts as a novel corepressor of thyroid hormone receptor and represses hepatic lipogenesis in mice. Journal of Hepatology 56 248-254. (doi:10.1016/ j.jhep.2011.07.014)

Stashi E, Lanz RB, Mao J, Michailidis G, Zhu B, Kettner NM, Putluri N, Reineke EL, Reineke LC, Dasgupta S, et al. 2014a Src2 is an essential coactivator for orchestrating metabolism and circadian rhythm. Cell Reports 6 633-645. (doi:10.1016/j.celrep.2014.01.027)

Stashi E, York B \& O'Malley BW 2014b Steroid receptor coactivators: Servants and masters for control of systems metabolism. Trends Endocrinology Metabolism 25 337-347. (doi:10.1016/j. tem.2014.05.004)

Strahl BD \& Allis CD 2000 The language of covalent histone modifications. Nature 403 41-45. (doi:10.1038/47412)

Suganuma T \& Workman JL 2008 Crosstalk among Histone Modifications. Cell 135 604-607. (doi:10.1016/j.cell.2008.10.036)

Sugrue ML, Vella KR, Morales C, Lopez ME \& Hollenberg AN 2010 The thyrotropin-releasing hormone gene is regulated by thyroid hormone at the level of transcription in vivo. Endocrinology 151 793-801. (doi:10.1210/en.2009-0976)

Sun Z, Feng D, Fang B, Mullican SE, You SH, Lim HW, Everett LJ, Nabel CS, Li Y, Selvakumaran V et al. 2013 Deacetylase-independent function of HDAC3 in transcription and metabolism requires nuclear receptor corepressor. Molecular Cell 52 769-782. (doi:10.1016/ j.molcel.2013.10.022)

Sutanto MM, Ferguson KK, Sakuma H, Ye H, Brady MJ \& Cohen RN 2010 The silencing mediator of retinoid and thyroid hormone receptors (SMRT) regulates adipose tissue accumulation and adipocyte insulin sensitivity in vivo. Journal of Biological Chemistry 285 18485-18495. (doi:10.1074/jbc.M110.107680)

Tagami T \& Jameson JL 1998 Nuclear corepressors enhance the dominant negative activity of mutant receptors that cause resistance to thyroid hormone. Endocrinology 139 640-650. (doi:10.1210/endo.139.2.5742)

Published by Bioscientifica Ltd 
Tagami T, Madison LD, Nagaya T \& Jameson JL 1997 Nuclear receptor corepressors activate rather than suppress basal transcription of genes that are negatively regulated by thyroid hormone. Molecular and Cellular Biology 17 2642-2648. (doi:10.1128/MCB.17.5.2642)

Takeshita A, Yen PM, Ikeda M, Cardona GR, Liu Y, Koibuchi N, Norwitz ER \& Chin WW 1998 Thyroid hormone response elements differentially modulate the interactions of thyroid hormone receptors with two receptor binding domains in the steroid receptor coactivator-1. Journal of Biological Chemistry 273 21554-21562. (doi:10.1074/jbc.273.34.21554)

Takeuchi Y, Murata Y, Sadow P, Hayashi Y, Seo H, Xu J, O'Malley BW, Weiss RE \& Refetoff S 2002 Steroid receptor coactivator-1 deficiency causes variable alterations in the modulation of $\mathrm{T}(3)$-regulated transcription of genes in vivo. Endocrinology 143 1346-1352. (doi:10.1210/endo.143.4.8730)

Tannour-Louet M, York B, Tang K, Stashi E, Bouguerra H, Zhou S, Yu H, Wong LJ, Stevens RD, Xu J, et al. 2014 Hepatic Src1 activity orchestrates transcriptional circuitries of amino acid pathways with potential relevance for human metabolic pathogenesis. Molecular Endocrinology 28 1707-1718. (doi:10.1210/me.2014-1083)

Tinnikov A, Nordstrom K, Thoren P, Kindblom JMU, Malin S, Rozell B, Adams M, Rajanayagam O, Pettersson S, Ohlsson C, et al. 2002 Retardation of post-natal development caused by a negatively acting thyroid hormone receptor alpha1. EMBO Journal 21 5079-5087. (doi:10.1093/emboj/cdf523)

Torchia J, Rose DW, Inostroza J, Kamei Y, Westin S, Glass CK \& Rosenfeld MG 1997 The transcriptional co-activator p/CIP binds CBP and mediates nuclear receptor function. Nature 387 677-684. (doi:10.1038/42652)

Tylki-Szymanska A, Acuna-Hidalgo R, Krajewska-Walasek M, Lecka-Ambroziak A, Steehouwer M, Gilissen C, Brunner HG, Jurecka A, Rozdzynska-Swiatkowska A, Hoischen A, et al. 2015 Thyroid hormone resistance syndrome due to mutations in the thyroid hormone receptor alpha gene (THRA).

Journal of Medical Genetics 52 312-316. (doi:10.1136/ jmedgenet-2014-102936)

van Mullem A, van Heerebeek R, Chrysis D, Visser E, Medici M, Andrikoula M, Tsatsoulis A, Peeters R \& Visser TJ 2012 Clinical phenotype and mutant TRalpha1. New England Journal of Medicine 366 1451-1453. (doi:10.1056/NEJMc1113940)

van Mullem AA, Visser TJ \& Peeters RP 2014 Clinical Consequences of Mutations in Thyroid Hormone Receptor-alpha1. European Thyroid Journal 3 17-24. (doi:10.1159/000360637)

Vella KR, Ramadoss P, Costa ESRH, Astapova I, Ye FD, Holtz KA, Harris JC \& Hollenberg AN 2014 Thyroid hormone signaling in vivo requires a balance between coactivators and corepressors. Molecular and Cellular Biology 34 1564-1575. (doi:10.1128/MCB.00129-14)

Vennstrom B, Mittag J \& Wallis K 2008 Severe psychomotor and metabolic damages caused by a mutant thyroid hormone receptor alpha 1 in mice: Can patients with a similar mutation be found and treated? Acta Paediatrica 97 1605-1610. (doi:10.1111/j.1651-2227.2008.01031.x)

Voegel JJ, Heine MJ, Tini M, Vivat V, Chambon P \& Gronemeyer H 1998 The coactivator TIF2 contains three nuclear receptor-binding motifs and mediates transactivation through CBP binding-dependent and -independent pathways. EMBO Journal 17 507-519. (doi:10.1093/ emboj/17.2.507)

Voegel JJ, Heine MJS, Zechel C, Chambon P \& Gronemeyer H 1996 TIF2, a $160 \mathrm{KD}$ transcriptional mediator for the ligand-dependent activation function AF-2 of nuclear receptors. EMBO Journal $\mathbf{1 5}$ 3667-3675. (doi:10.1093/emboj/17.2.507)

Wang L, Zuercher WJ, Consler TG, Lambert MH, Miller AB, Orband-Miller LA, McKee DD, Willson TM \& Nolte RT 2006 $\mathrm{X}$-ray crystal structures of the estrogen-related receptor-gamma ligand binding domain in three functional states reveal the molecular basis of small molecule regulation. Journal of
Biological Chemistry 281 37773-37781. (doi:10.1074/ jbc.M608410200)

Wang Z, Rose DW, Hermanson O, Liu F, Herman T, Wu W, Szeto D, Gleiberman A, Krones A, Pratt K et al. 2000 Regulation of somatic growth by the p160 coactivator p/CIP. PNAS 97 13549-13554. (doi:10.1073/pnas.260463097)

Watson PJ, Fairall L \& Schwabe JW 2012 Nuclear hormone receptor co-repressors: Structure and function. Molecular and Cellular Endocrinology 348 440-449. (doi:10.1016/ j.mce.2011.08.033)

Webb P, Anderson CM, Valentine C, Nguyen P, Marimuthu A, West BL, Baxter JD \& Kushner PJ 2000 The nuclear receptor corepressor (NCoR) contains three isoleucine motifs (I/LXXII) that serve as receptor interaction domains (IDs). Molecular Endocrinology 14 1976-1985. (doi:10.1210/mend.14.12.0566)

Weinberger C, Thompson CC, Ong ES, Lebo R, Gruol DJ \& Evans RM 1986 The c-erb-A gene encodes a thyroid hormone receptor. Nature 324 641-646. (doi:10.1038/324641a0)

Weiss RE, Gehin M, Xu J, Sadow PM, O'Malley BW, Chambon P \& Refetoff S 2002 Thyroid function in mice with compound heterozygous and homozygous disruptions of Src1 and TIF-2 coactivators: Evidence for haploinsufficiency. Endocrinology 143 1554-1557. (doi:10.1210/endo.143.4.8828)

Weiss RE, Hayashi Y, Nagaya T, Petty KJ, Murata Y, Tunca H, Seo H \& Refetoff S 1996 Dominant inheritance of resistance to thyroid hormone not linked to defects in the thyroid hormone receptor alpha or beta genes may be due to a defective cofactor. Journal of Clinical Endocrinology and Metabolism $\mathbf{8 1}$ 4196-4203. (doi:10.1210/jcem.81.12.8954015)

Weiss RE, Xu J, Ning G, Pohlenz J, O'Malley BW \& Refetoff S 1999 Mice deficient in the steroid receptor co-activator $1(\mathrm{Src} 1)$ are resistant to thyroid hormone. EMBO Journal 18 1900-1904. (doi:10.1093/ emboj/18.7.1900)

Wong J, Shi YB \& Wolffe AP 1995 A role for nucleosome assembly in both silencing and activation of the Xenopus TR beta A gene by the thyroid hormone receptor. Genes \& Development 9 2696-2711. (doi:10.1101/gad.9.21.2696)

Wood WM, Kao MY, Gordon DF \& Ridgeway EC 1989 Thyroid hormone regulates the mouse thyrotropin ?-subunit promoter in transfected primary thyrotropes. Journal of Biological Chemistry $\mathbf{6 1}$ 497-504.

Wu Y, Delerive P, Chin WW \& Burris TP 2002 Requirement of helix 1 and the AF-2 domain of the thyroid hormone receptor for coactivation by PGC-1. Journal of Biological Chemistry $\mathbf{2 7 7}$ 8898-8905. (doi:10.1074/jbc.M110761200)

Xu HE, Stanley TB, Montana VG, Lambert MH, Shearer BG, Cobb JE, McKee DD, Galardi CM, Plunket KD, Nolte RT, et al. 2002 Structural basis for antagonist-mediated recruitment of nuclear co-repressors by PPARalpha. Nature 415 813-817. (doi:10.1038/415813a)

Xu J \& Li Q 2003 Review of the in vivo functions of the p160 steroid receptor coactivator family. Molecular Endocrinology 17 1681-1692. (doi:10.1210/me.2003-0116)

Xu J, Liao L, Ning G, Yoshida-Komiya H, Deng C \& O'Malley BW 2000 The steroid receptor coactivator $\operatorname{Src3}$ (p/CIP/RAC3/ AIB1/ACTR/TRAM-1) is required for normal growth, puberty, female reproductive function, and mammary gland development. PNAS 97 6379-6384. (doi:10.1073/ pnas.120166297)

Xu J, Qiu Y, DeMayo FJ, Tsai SY, Tsai MJ \& O’Malley BW 1998 Partial hormone resistance in mice with disruption of the steroid receptor coactivator-1 (Src1) gene. Science 279 1922-1925. (doi:10.1126/ science.279.5358.1922)

Xu L, Glass CK \& Rosenfeld MG 1999 Coactivator and corepressor complexes in nuclear receptor function. Current Opinion in Genetics \& Development 9 140-147. (doi:10.1016/S0959-437X(99)80021-5)

Published by Bioscientifica Ltd. 
Yamamoto H, Williams EG, Mouchiroud L, Canto C, Fan W, Downes M, Heligon C, Barish GD, Desvergne B, Evans RM, et al. 2011 NCoR1 is a conserved physiological modulator of muscle mass and oxidative function. Cell 147 827-839. (doi:10.1016/ j.cell.2011.10.017)

Yang Z \& Privalsky ML 2001 Isoform-specific transcriptional regulation by thyroid hormone receptors: Hormone-independent activation operates through a steroid receptor mode of co-activator interaction. Molecular Endocrinology 15 1170-1185. (doi:10.1210/ mend.15.7.0656)

Yao X, Xia H, Wang Y \& Ying H. 2014 Thyroid hormone receptor coregulators in metabolic regulation. Journal of Endocrinology, Diabetes and Obesity 21051.

Yoh SM, Chatterjee VK \& Privalsky ML 1997 Thyroid hormone resistance syndrome manifests as an aberrant interaction between mutant T3 receptors and transcriptional corepressors. Molecular Endocrinology 11 470-480. (doi:10.1210/mend.11.4.9914)

Yoon HG, Chan DW, Huang ZQ, Li J, Fondell JD, Qin J \& Wong J 2003 Purification and functional characterization of the human NCoR complex: The roles of HDAC3, TBL1 and TBLR1. EMBO Journal 22 1336-1346. (doi:10.1093/emboj/cdg120)
York B, Reineke EL, Sagen JV, Nikolai BC, Zhou S, Louet JF, Chopra AR, Chen X, Reed G, Noebels J, et al. 2012 Ablation of steroid receptor coactivator-3 resembles the human CACT metabolic myopathy. Cell Metabolism 15 752-763. (doi:10.1016/ j.cmet.2012.03.020)

You SH, Liao X, Weiss RE \& Lazar MA 2010 The interaction between nuclear receptor corepressor and histone deacetylase 3 regulates both positive and negative thyroid hormone action in vivo. Molecular Endocrinology 24 1359-1367. (doi:10.1210/ me.2009-0501)

You SH, Lim HW, Sun Z, Broache M, Won KJ \& Lazar MA 2013 Nuclear receptor co-repressors are required for the histone-deacetylase activity of HDAC3 in vivo. Nature Structural \& Molecular Biology 20 182-187. (doi:10.1038/nsmb.2476)

Zhang J \& Lazar MA 2000 The mechanism of action of thyroid hormones. Annual Review of Physiology 62 439-466. (doi:10.1146/ annurev.physiol.62.1.439)

Zilz ND, Murray MB \& Towle HC 1990 Identification of multiple thyroid hormone response elements located far upstream from the rat S14 promoter. Journal of Biological Chemistry 265 8136-8143.

Received in final form 8 December 2015

Accepted 16 December 2015

Accepted Preprint published online 16 December 2015 